\title{
Distribución, composición y abundancia del ictioplancton en tres áreas marinas protegidas del Pacífico colombiano
}

\section{Distribution, composition, and abundance of ichthyoplankton in three marine protected areas of the Colombian Pacific}

\author{
Beatriz Susana Beltrán-León ${ }^{\prime}$ y Yaneth Alicia Morales Osorio ${ }^{2}$ \\ (iD) $0000-0002-4399-3642 \quad$ (iD) $0000-0001-9743-4056$ \\ 1. Investigadora Independiente, Carrera 47 \#2A-75 Apto 102 G. Cali, Colombia E-mail: bbeltranleon@yahoo.com* \\ 2. Investigadora Independiente, Carrera 22A -6-05 Oeste. Cali, Colombia E-mail: ymoralesosorio@gmail.com \\ * Autora para correspondencia.
}

\section{RESUMEN}

\begin{abstract}
$\mathrm{C}$ on el propósito de caracterizar el ictioplancton en tres áreas marinas protegidas (Parque Nacional Natural Sanquianga, Parque Nacional Natural Gorgona y Santuario de Fauna y Flora Malpelo) en el Pacífico colombiano durante noviembre de 2009, se realizaron expediciones científicas para obtener 56 muestras mediante el arrastre con redes bongo. Se capturaron $3155 / 10 \mathrm{~m}^{2}$ larvas de peces distribuidas en 1553 larvas/10 $\mathrm{m}^{2}$ (49,22\%) para el PNN Sanquianga; 1411 larvas/10 m² (44,72 \%) para el PNN Gorgona y 191 larvas/10 $\mathrm{m}^{2}$ (6,05 \%) para el SFF Malpelo. Las principales familias fueron Engraulidae (PNN Sanquianga), Bregmacerotidae (PNN Gorgona) y Phosichthyidae (SFF Malpelo). El análisis de comunidades evidencia que la ubicación de las áreas, PNN Sanquianga (costera), PNN Gorgona (intermedia) y SFF Malpelo (oceánica), marca una clara diferencia en la composición, distribución y abundancia de las larvas. Se encontraron por primera vez huevos de la familia Engraulidae en el área de Malpelo, no habitual en su distribución, coincidiendo con lo registrado por el Boletín de Alerta Climática (BAC, 2009) de julio de 2009, que plantea el desarrollo de un evento El Niño, que se extendió hasta el primer trimestre de 2010.
\end{abstract}

PALABRAS CLAVES: Áreas marinas protegidas, ictioplancton, Pacífico colombiano, larvas de peces.

\section{ABSTRACT}

$\mathrm{W}$ ith the purpose of characterizing ichthyoplankton in three marine protected areas (Sanquianga National Natural Park, Gorgona National Natural Park and Malpelo Fauna and Flora Sanctuary) in the Colombian Pacific during November 2009, scientific expeditions were carried out to obtain 56 samples by trawling with bongo nets. $3,155 / 10 \mathrm{~m}^{2}$ fish larvae were captured distributed in 1,553 larvae / $10 \mathrm{~m}^{2}$ (49.22 \%) for the PNN Sanquianga; 1,411 larvae / 10 $\mathrm{m}^{2}(44.72 \%)$ for the Gorgona PNN and 191 larvae $/ 10 \mathrm{~m}^{2}(6.05 \%)$ for the Malpelo SFF. The main families were Engraulidae (PNN Sanquianga), Bregmacerotidae (PNN Gorgona) and Phosichthyidae (SFF Malpelo). The NMS community analysis shows that the location of the PNN Sanquianga (coastal), PNN Gorgona (intermediate) and SFF Malpelo (oceanic) areas, marks a clear difference in the composition, distribution and abundance of the larvae. Eggs of Engraulidae were found for the first time in the Malpelo area, an unusual area in its distribution, coinciding with what was reported by the Climate Alert Bulletin (BAC, 2009) of July 2009, which reports the development of an El Niño event, which lasted until the first quarter of 2010.

KEY WORDS: marine protected areas, ichthyoplankton, Colombian Pacific, fish larvae.

DOI: https://doi.org/10.25268/bimc.invemar.2021.50.2.1062 Publicado por INVEMAR

Este es un manuscrito de acceso abierto bajo la licencia CC

Reconocimiento-No Comercial-Compartir Igual 


\section{INTRODUCCIÓN}

El ictioplancton es un componente importante del zooplancton marino y los factores que tienen influencia sobre la distribución y abundancia de este, son los mismos que para otros pláncteres: la necesidad de alimento (alimento adecuado en el momento preciso y en cantidad suficiente), la incidencia de depredadores, incluyendo los mecanismos que eviten la depredación, la influencia de la temperatura, la salinidad, las corrientes y otros factores físicos y químicos (Giraldo et al., 2014). Ecológicamente su importancia radica en que como componente estructural y funcional de los ecosistemas acuáticos muestra a través de la variabilidad de su composición y abundancia, la calidad o el deterioro del medio que ocupa (Beltrán-León y Ríos, 2000). Las áreas marinas protegidas: Parque Nacional Natural (PNN) Gorgona, PNN Sanquianga y Santuario de Fauna y Flora (SFF) Malpelo, juegan un papel muy importante en la dispersión y reclutamiento de larvas claves para el mantenimiento y repoblación de los recursos pesqueros en las aguas circundantes, como ha sido registrado en otras islas alrededor del mundo (Swearer et al., 1999). El auge de la explotación de recursos pesqueros en aguas costeras y oceánicas del Pacífico colombiano, ha generado un aumento en la presión de uso de las áreas de pesca, incrementando el interés hacia las zonas protegidas. Por lo tanto, para enfrentar este reto de uso, se requiere modificar el estilo de desarrollo, tomando y llevando a cabo decisiones que integren la conservación, el uso sostenible y la participación equitativa de los beneficios, sin afectar las condiciones fundamentales para la vida y su desarrollo (Beltrán-León y Ríos, 2000). En este contexto, el estudio del ictioplancton se convierte en un medio relevante para evaluar el estado del stock íctico de una localidad, ya que permite establecer información sobre la composición, diversidad y potencial productivo de una región, y simultáneamente identificar las áreas y periodos críticos para el desarrollo del recurso (BeltránLeón y Ríos, 2000). La Dirección Territorial Suroccidente (DTSO) ahora Dirección Territorial Pacífico (DTPA) del Sistema de Parques Nacionales Naturales, con apoyo de la Fundación Malpelo y parciales de WWF Colombia y Conservación Internacional a través de proyectos de cooperación, desarrollaron durante noviembre de 2009, diferentes expediciones científicas a los PNN Sanquianga y Gorgona y el SFF Malpelo, con el objetivo de caracterizar el plancton presente en las tres áreas protegidas y poder brindar información sobre los huevos y larvas de peces, determinar áreas de desove y cría y la relación e influencia

\section{INTRODUCTION}

Ichthyoplankton are an important component of marine zooplankton and the factors that influence its distribution and abundance are the same as those affecting other plankton: food requirements (adequate dietary availability at appropriate times and in sufficient quantities), the presence of predators (including methods to avoid predation) and the influence of temperature, salinity, currents and other physical and chemical factors (Giraldo et al., 2014). Their ecological importance lies in the fact that, as structural and functional components of aquatic ecosystems, variability in their composition and abundance illustrates their quality of their surroundings or its deterioration (Beltrán-León and Ríos, 2000). The marine protected areas of the Gorgona and Sanquianga Natural National Parks (NNPs) and the Malpelo Fauna and Flora Sanctuary (FFS) play a very important role in the dispersal and recruitment of larvae, which are key to the maintenance and restocking of fishery resources in surrounding waters, as has been observed for islands in other parts of the world (Swearer et al., 1999). Increased exploitation of coastal and oceanic waters of the Colombian Pacific has increased pressures on fishing grounds and led to increased interest in extending this exploitation to protected areas. Approaches to sustainable development must therefore be adjusted in response to these challenges, and decisions taken and implemented that incorporate conservation, the sustainable use of resources and the equitable share of benefits of development, without affecting the fundamental conditions required for the continuation of life (Beltrán-León and Ríos, 2000). Consequently, studies of ichthyoplankton are important for evaluating fish stocks in a given area, making it possible to establish information on the composition, diversity and productive potential of a zone while simultaneously identifying the areas and periods that are critical to the development of fisheries resources (BeltránLeón and Ríos, 2000). In November 2009 the Dirección Territorial Suroccidente (Southwest Territorial Directorate) now known as the Dirección Territorial Pacífico (Pacific Territorial Directorate), part of the Sistema de Parques Nacionales Naturales (System of Natural National Parks), carried out a series of scientific expeditions to the Sanquianga and Gorgona NNPs and the Malpelo FFS, in order to gather information on fish eggs and larvae, determine spawning areas and nurseries and establish the role and influence of the environment on the early stages of life. The scientific expeditions also produced an inventory of biodiversity, 
del medio ambiente sobre el desarrollo de vida temprana. Además de obtener un inventario de la biodiversidad de especies que a futuro y mediante muestreos periódicos (monitoreos) coadyuve a la toma de decisiones que integran la conservación y el uso sostenible de los recursos.

\section{ÁREA DE ESTUDIO}

Las áreas protegidas PNN Gorgona $\left(02^{\circ} 58^{\prime} 17^{\prime \prime} \mathrm{N}\right.$ $\left.78^{\circ} 11^{\prime} 04^{\prime \prime} \mathrm{W}\right)$, PNN Sanquianga ( $\left.2^{\circ} 38^{\prime} 59^{\prime \prime}-78^{\circ} 17^{\prime} 09^{\prime \prime} \mathrm{W}\right)$ y SFF Malpelo (Punto 1: $4^{\circ} 26^{\prime} 00^{\prime \prime} \mathrm{N}-82^{\circ} 00^{\prime} 00^{\prime \prime} \mathrm{W}$, Punto 2: $4^{\circ} 26^{\prime} 00^{\prime \prime} \mathrm{N}-81^{\circ} 08^{\prime} 00^{\prime \prime} \mathrm{W}$, Punto3: $3^{\circ} 32^{\prime} 00^{\prime \prime} \mathrm{N}-$ $82^{\prime} 00^{\prime} 00^{\prime \prime} \mathrm{W}$, Punto 4: $3^{\circ} 32^{\prime} 00^{\prime \prime} \mathrm{N}-81^{\circ} 08^{\prime} 00^{\prime \prime} \mathrm{W}$ ), hacen parte de las 59 áreas protegidas del Sistema Nacional de Parques y están ubicadas en la zona costera y oceánica del Pacífico colombiano (Figura 1). that, in conjunction with periodic monitoring, will make it possible for future decision-making to incorporate conservation practices and the sustainable use of resources.

\section{STUDY AREA}

The protected areas of the Gorgona NNP $\left(02^{\circ} 58^{\prime} 17^{\prime \prime} \mathrm{N}-78^{\circ} 11^{\prime} 04^{\prime \prime} \mathrm{W}\right)$, the Sanquianga NNP $\left(2^{\circ} 38^{\prime} 59^{\prime \prime}-78^{\circ} 17^{\prime} 09^{\prime \prime} \mathrm{W}\right)$ and the Malpelo FFS (Point 1: $4^{\circ} 26^{\prime} 00^{\prime \prime} \mathrm{N}-82^{\circ} 00^{\prime} 00^{\prime \prime} \mathrm{W}$, Point 2: $4^{\circ} 26^{\prime} 00^{\prime \prime} \mathrm{N}$ $81^{\circ} 08^{\prime} 00^{\prime \prime} \mathrm{W}$, Point 3: $3^{\circ} 32^{\prime} 00^{\prime \prime} \mathrm{N}-82^{\prime} 00^{\prime} 00^{\prime \prime} \mathrm{W}$, Point 4: $3^{\circ} 32^{\prime} 00^{\prime \prime} \mathrm{N}-81^{\circ} 08^{\prime} 00^{\prime \prime} \mathrm{W}$ ), are among the 59 protected areas covered by the Natural National Parks System. They are located in the coastal and oceanic zone of the Colombian Pacific (Figure 1).

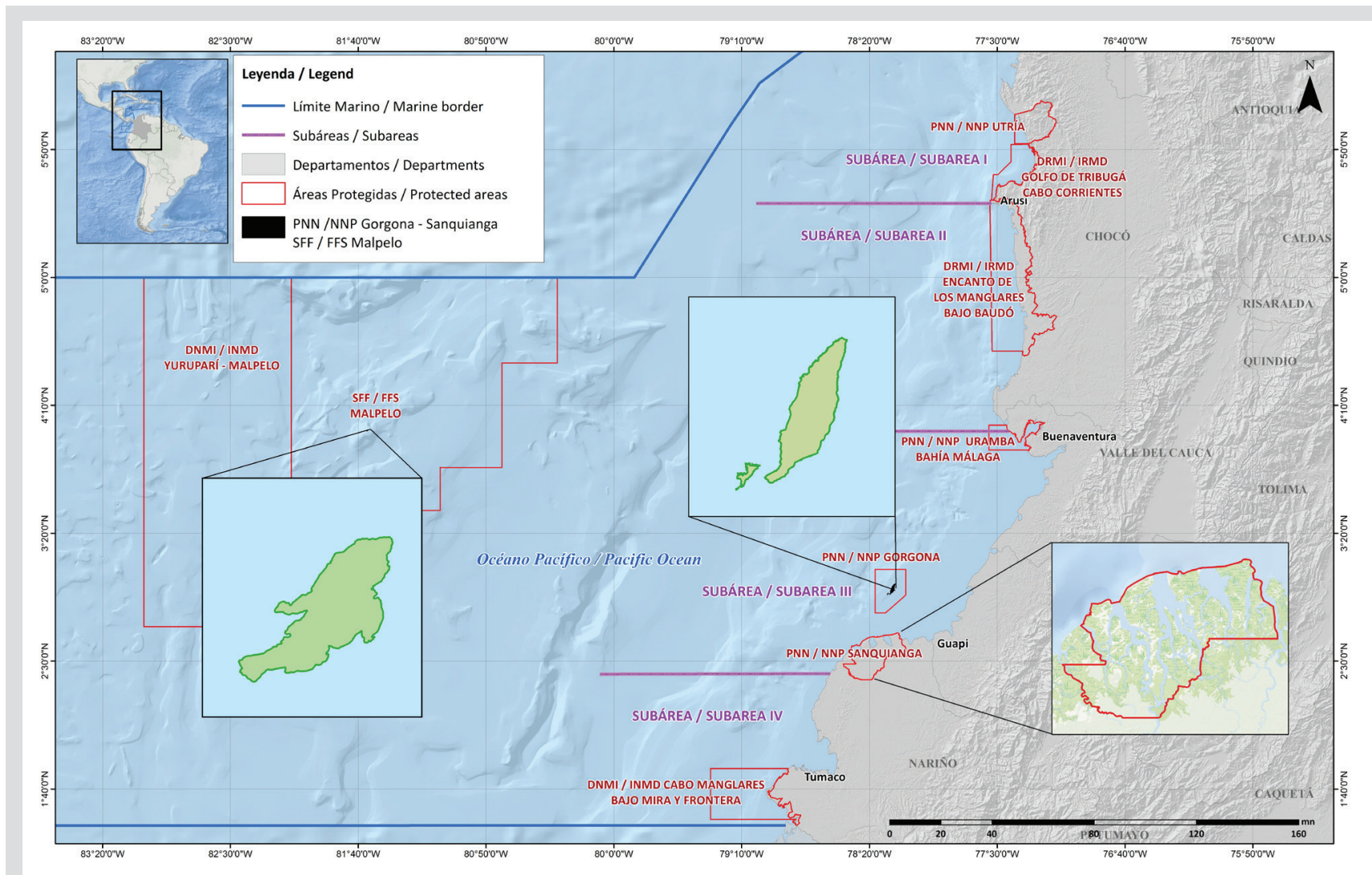

Figura 1. Ubicación de las áreas protegidas Parque Nacional Natural Sanquianga, Parque Nacional Natural Gorgona y Santuario de Fauna y Flora Malpelo en el Pacífico colombiano (elaborada por: Leydi Cuadros, WWF-Colombia).
Figure 1. Location of the protected areas of the Sanquianga and Gorgona National Natural Parks and the Malpelo Fauna and Flora Sanctuary in the Colombian Pacific (prepared by Leydi Cuadros, WWF-Colombia). 


\section{MATERIALES Y MÉTODOS}

Se siguió un plan de muestreo de 24 estaciones en la zona marina frente al PNN Sanquianga, grilla establecida por el Proyecto Pequeños Pelágicos de WWF Colombia - Min Agricultura 2008 (Zapata et al., 2011); 24 estaciones alrededor del PNN Gorgona, grilla establecida por el proyecto Univalle - Colciencias 2006 (Escarria et al., 2007) y 12 estaciones alrededor del SFF Malpelo, grilla establecida por el Proyecto INPA - DIMAR 1993 (Beltrán-León, 2007), durante noviembre de 2009 para las tres áreas (Figura 2).

\section{MATERIALS AND METHODS}

The sampling plan consisted of 24 stations located in the marine area offshore from the Sanquianga NNP, using a grid established by the 2008 joint WWF-Colombia/Ministry of Agriculture Small Pelagics Project (Small Ocean Projects) (Zapata et al., 2011), a further 24 stations in the Gorgona NNP, using a grid established by the 2006 Univalle - Colciencias project (Escarria et al., 2007), and 12 stations off the coast of the Malpelo FFS, using a grid established by the 1993 INPA - DIMAR project (Beltrán-León, 2007). All samples were taken during November 2009 (Figure 2).

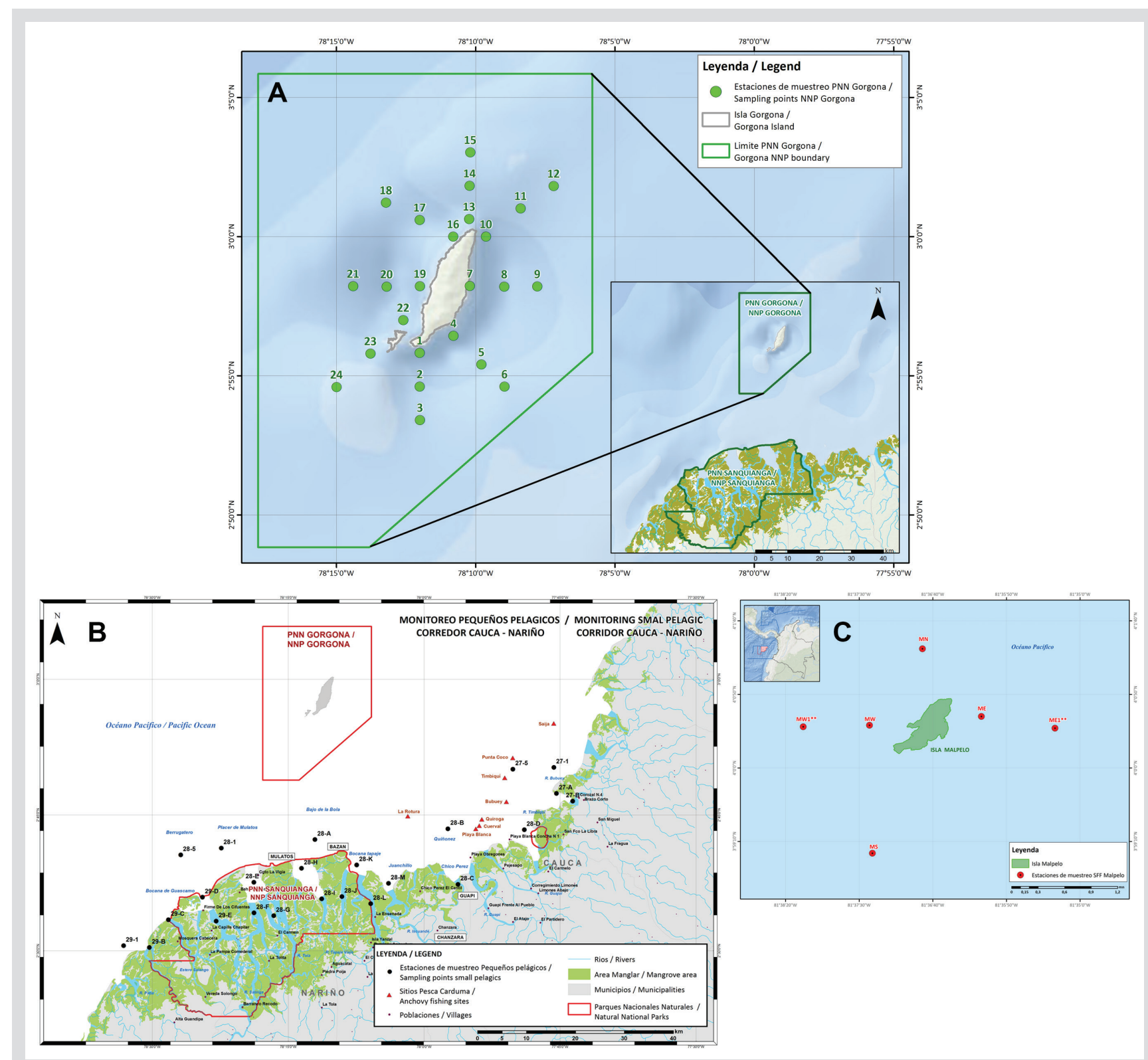

Figura 2. Ubicación de las estaciones de muestreo A. PNN Gorgona, B. PNN Sanquianga y C. SFF Malpelo, Pacífico colombiano.
Figure 2. Location of the sampling stations A. Gorgona NNP, B. Sanquianga NNP and C. Malpelo FFS, Colombian Pacific. 
Se realizaron arrastres superficiales de zooplancton para el PNN Sanquianga (24 estaciones) y el SFF Malpelo (12 estaciones) y por logística y diseño de muestreo para el PNN Gorgona (24 estaciones) oblicuos hasta una profundidad máxima de $50 \mathrm{~m}$, de acuerdo con la metodología establecida por Smith y Richardson (1979), utilizando redes bongo de 300 y $500 \mu \mathrm{m}$, provistas de copos colectores blandos y contadores de flujo análogos Hydrobios. Las muestras fueron preservadas con formalina buferizada al $10 \%$ en agua de mar. Todos los arrastres se realizaron a una velocidad de $3,7 \mathrm{~km} / \mathrm{h}$. Simultáneamente, en cada estación se registró la temperatura y la salinidad superficial, utilizando un sistema portátil para medición de conductividad, salinidad y temperatura YSI, mientras la transparencia en la columna de agua se midió con un disco Secchi. Una vez trasladadas las muestras desde las áreas al laboratorio en la ciudad de Cali, se midió la biomasa zooplanctónica por el método volumétrico y se separó el total de huevos y larvas de peces (ictioplancton) del resto del zooplancton (invertebrados planctónicos), colectado en la malla de $300 \mu \mathrm{m}$.

Las larvas de peces fueron identificadas con base en los caracteres merísticos, morfométricos y de pigmentación, hasta el menor nivel taxonómico posible (familia, género y/o especie), siguiendo las claves de identificación de Moser (1996) y Beltrán-León y Ríos (2000). Para todos los casos el número de organismos se estandarizó a ind/10 $\mathrm{m}^{2}$. Para los análisis se tomaron como referencia los rangos de salinidad, temperatura y abundancia registrados por Rueda-Montenegro y Beltrán-León (1992) y modificados por Beltrán-León et al. (1994) (Tabla 1). Para todos los análisis se trabajó con un nivel de significancia de $5 \%$. Las correlaciones entre las dos variables físicoquímicas (temperatura y salinidad) y las cinco variables biológicas (biovolumen zooplanctónico, huevos de peces, larvas de peces, huevos de Engraulidae y larvas de Engraulidae) se evaluaron con la prueba para correlación de Pearson. Para la comparación entre las tres áreas protegidas, de acuerdo con cada una de las siete variables (las dos variables fisicoquímicas y las cinco variables biológicas), se siguió la siguiente ruta:

a. Evaluación de normalidad en cada uno de los tres subconjuntos de datos, con la prueba de Lilliefors (Kolmogorov-Smirnov).

b. Evaluación de homocedasticidad entre los tres subconjuntos de datos, con la prueba Fligner-Killeen.

c. Evaluación de igualdad de medias (o medianas, según sea el caso): i. Si hay normalidad y homocedasticidad,
Surface trawls for zooplankton were conducted in the Sanquianga NNP (24 stations) and the Malpelo FFS (12 stations), while for logistical reasons and because of the nature of the sample design, oblique trawls were conducted in the Gorgona NNP (24 stations) to a maximum depth of $50 \mathrm{~m}$, using the methodology established by Smith and Richardson (1979). The samples were collected using bongo nets of 300 and $500 \mu \mathrm{m}$ and Hydrobios analogue flowmeter. Samples were preserved using formalin buffered at $10 \%$ in sea water. All the trawls were carried out at a speed of $3.7 \mathrm{~km} / \mathrm{h}$. Simultaneously, surface temperature and salinity were measured for all stations using a YSI portable system to measure conductivity, salinity and temperature; water column transparency was recorded using a Secchi disk. Once the samples had been transferred from the sampling zones to the laboratory in the city of Cali, the biomass of the zooplankton was determined using the volumetric method and the fish eggs and larvae (ichthyoplankton) were separated from the rest of the zooplankton (planktonic invertebrates), which had been collected using the $300 \mu \mathrm{m}$ net.

The fish larvae were identified by their meristic and morphometric characteristics and pigmentation to the lowest taxonomic level possible (family, genus and/ or species), using the identification criteria developed by Moser (1996) and Beltrán-León and Ríos (2000). In all cases the number of organisms was standardized to individuals $/ 10 \mathrm{~m}^{2}$. The salinity, temperature and abundance ranges recorded by Rueda-Montenegro and Beltrán-León (1992), and modified by Beltrán-León et al. (1994), were used for reference (Table 1). A $5 \%$ significance level of was employed in all the analyses. The correlations between the two physico-chemical variables (temperature and salinity) and the five biological ones (zooplanktonic biovolume, fish eggs, fish larvae and Engraulidae eggs and larvae) were examined using the Pearson correlation coefficient. The following steps were adhered to in order to compare the seven variables (two physico-chemical and five biological) in the three protected areas:

a. Normality test for each of the three subsets of data, using the Lilliefors test (Kolmogorov-Smirnov).

b. Homoscedasticity test between the three subsets of data, using the Fligner-Killeen test.

c. Means equality test (or averages depending on the case): i. If normality and homoscedasticity were found, using a standard ANOVA. ii. In the event of normality and 
con una ANOVA estándar. ii. Si hay normalidad y heterocedasticidad, con una ANOVA de Welch. iii. Si no hay normalidad, las distribuciones son semejantes, y hay homocedasticidad, con una ANOVA no paramétrica de Kruskal-Wallis. iv. Si no hay normalidad, las distribuciones son semejantes, $\mathrm{y}$ hay heterocedasticidad, con la técnica no paramétrica de bootstrap (Hesterberg, 2015).

Se evaluó el grado de asociación entre abundancia de larvas de peces y parámetros fisicoquímicos, mediante correlación no-paramétrica de un análisis NMS y la matriz ambiental. Toda la información obtenida del muestreo y los análisis en el laboratorio se estandarizaron a individuos $/ 10 \mathrm{~m}^{2}$ con el fin de hacer los datos comparables. homoscedasticity, using a Welch ANOVA. iii. If there was no normality, the distributions were similar and therefore homoscedasticity was found, using a non-parametric Kruskal-Wallis ANOVA. iv. If there was no normality, the distributions were similar and there was heteroscedasticity, using a non-parametric Bootstrap ANOVA (Hesterberg, 2015).

The degree of association between the abundance of fish larvae and physico-chemical parameters was evaluated using a non-parametric correlation of an analysis with nMDS (non-Metric Multidimensional Scaling) and the environmental matrix. All the information obtained from the sample and the laboratory analyses were standardized to individuals $/ 10 \mathrm{~m}^{2}$ in order to render the data comparable.

Tabla 1. Rangos de salinidad, temperatura y abundancia/

Table 1. Salinity, temperature and abundance ranges

\begin{tabular}{|c|c|c|c|}
\hline Rango / Rank & Abundancia / Abundance (ind/10 $\left.\mathbf{m}^{2}\right)$ & Temperatura / Temperature $\left({ }^{\circ} \mathbf{C}\right)$ & Salinidad / Salinity \\
\hline Bajo / Low & $1-99$ & $<25.99$ & $<28.99$ \\
Medio / Medium & $100-499$ & $26.00-27.99$ & $29.00-31.99$ \\
\hline Alto / High & $>500$ & $>28.00$ & $>32.00$ \\
\hline
\end{tabular}

\section{RESULTADOS}

\section{Condiciones oceanográficas}

La temperatura superficial del mar-TSM, durante noviembre de 2009 osciló entre 26,5 y $29,2{ }^{\circ} \mathrm{C}$, el valor promedio más bajo se encontró en Gorgona, aumentando en $0,2{ }^{\circ} \mathrm{C}$ para Sanquianga y en $0,9{ }^{\circ} \mathrm{C}$ para Malpelo. Los datos de TSM para Sanquianga y Malpelo pueden ser considerados con distribución normal ( $p=0,596$ y 0,138$)$, pero no para Gorgona $(\mathrm{p}=0,015)$, siendo estadísticamente diferentes entre las tres áreas $(p<0,001)$, Malpelo es de mayor temperatura que Sanquianga y Gorgona ( $\mathrm{p}<0,001)$, pero Sanquianga y Gorgona no son diferentes entre sí $(\mathrm{p}=0,691)$ (Figura 3, Tabla 2).

La salinidad superficial del mar-SSM, osciló entre 2,9 y 35 ; con el valor promedio de salinidad más bajo en Sanquianga, aumentando en 10,9 para Gorgona y 13,2 para Malpelo. Los datos de salinidad para Sanquianga y Gorgona pueden ser considerados con distribución normal $(\mathrm{p}=0,073$ y 0,056$)$, pero no para Malpelo $(\mathrm{p}=0,007)$. Las salinidades superficiales son estadísticamente diferentes entre las tres áreas ( $\mathrm{p}<0,001)$, siendo mayor en Malpelo, seguida de Gorgona y menor en Sanquianga ( $<<0,003$ ). (Figura 3, Tabla 2).

\section{RESULTS}

\section{Oceanographic conditions}

Sea surface temperature (SST) during November 2009 oscillated between 26.5 and $29.2{ }^{\circ} \mathrm{C}$. The lowest temperature was recorded in Gorgona, rising by $0.2^{\circ} \mathrm{C}$ in Sanquianga and by $0.9{ }^{\circ} \mathrm{C}$ in Malpelo. The SST data for Sanquianga and Malpelo is considered normally distributed ( $p=0.596$ and 0.138 ), but this was not the case for Gorgona $(\mathrm{p}=0.015)$, which was statistically different $(\mathrm{p}<0.001)$. The temperatures around Malpelo are higher than those of Sanquianga and Gorgona ( $p<0.001)$, but Sanquianga and Gorgona do not differ between themselves $(p=0.691)$ (Figure 3, Table 2).

Sea surface salinity (SSS) oscillated between 2.9 and 35, with average salinity lowest in Sanquianga, increasing by 10.9 in Gorgona and by 13.2 in Malpelo. The salinity data for Sanquianga and Gorgona is considered normally distributed $(\mathrm{p}=0.073$ and 0.056$)$, but not for Malpelo $(p=0.007)$. Sea surface salinities differed statistically between the three areas $(\mathrm{p}<0.001)$, levels being highest in Malpelo, followed by Gorgona and Sanquianga $(\mathrm{p}<0.003)$. (Figure 3, Table 2). 
Tabla 2. Temperatura superficial del $\operatorname{mar}\left(\mathrm{TSM}^{\circ} \mathrm{C}\right)$ y salinidad superficial del mar (SSM) en el PNN Sanquianga, PNN Gorgona y SFF Malpelo, Pacífico colombiano, durante noviembre de 2009.
Table 2. Sea Surface Temperature $\left(\mathrm{SST}^{\circ} \mathrm{C}\right)$ and Sea Surface Salinity and (SSS) in the Sanquianga and Gorgona NNPs and Malpelo FFS, Colombian Pacific, November 2009.

\begin{tabular}{|c|c|c|c|c|c|c|c|}
\hline Áreas / Location & $\begin{array}{c}\text { TSM / SST } \\
\left({ }^{\circ} \text { C) Min }\right.\end{array}$ & $\begin{array}{c}\text { TSM / SST }\left({ }^{\circ} \mathbf{C}\right) \\
\text { Max }\end{array}$ & $\begin{array}{c}\text { Promedio / } \\
\text { Average }\end{array}$ & $\begin{array}{c}\text { SSM / SSS } \\
\text { Min }\end{array}$ & $\begin{array}{c}\text { SSM / SSS } \\
\text { Max }\end{array}$ & $\begin{array}{c}\text { Promedio / } \\
\text { Average }\end{array}$ & $\begin{array}{c}\text { N (Estaciones) / } \\
\text { (Stations) }\end{array}$ \\
\hline PNN Sanquianga & 26.5 & 29.2 & $27.9(+/-0.67)$ & 2.9 & 30.1 & $19.3(+/-8.21)$ \\
PNN Gorgona & 27.3 & 28.4 & $27.7(+/-0.31)$ & 28.2 & 30.7 & $30.2(+/-0.55)$ & 24 \\
\hline SFF Malpelo & 28.3 & 28.2 & $28.6(+/-0.29)$ & 31.0 & 35 & $32.5(+/-3.11)$ \\
\hline
\end{tabular}

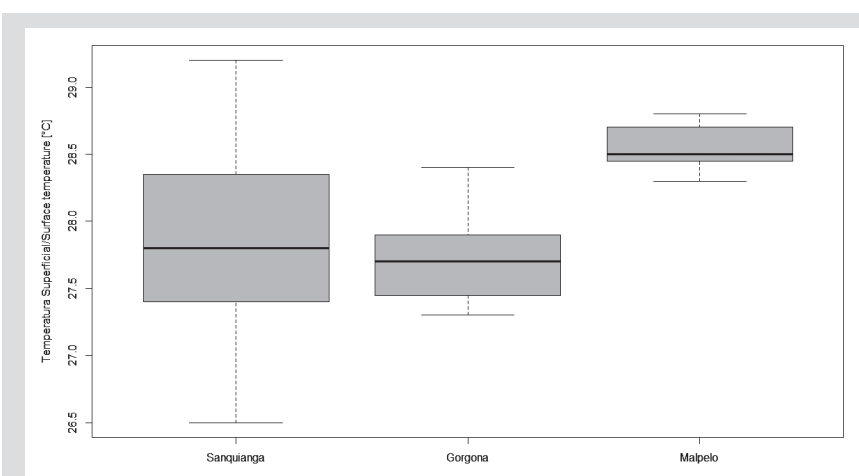

Figura 3. Temperatura superficial del $\operatorname{mar}\left({ }^{\circ} \mathrm{C}\right)$ (izquierda) y salinidad superficial del mar (derecha), en el PNN Sanquianga, PNN Gorgona y SFF Malpelo, Pacífico colombiano, durante noviembre de 2009.

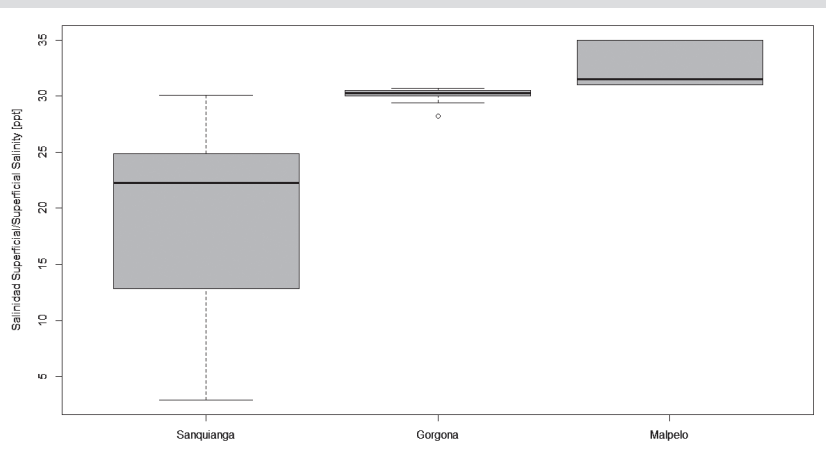

Figure 3. Sea surface temperature $\left({ }^{\circ} \mathrm{C}\right)(\mathrm{left})$ and sea surface salinity (right) in the Sanquianga and Gorgona NNPs and the Malpelo FFS, Colombian Pacific, November 2009.

\section{Biomasa zooplanctónica}

El biovolumen zooplanctónico osciló entre 24,7 y $455,6 \mathrm{ml} / 1000 \mathrm{~m}^{3}$. Los datos de biovolumen para Malpelo pueden ser considerados con distribución normal $(\mathrm{p}=0,115)$, no para Sanquianga y Gorgona $(\mathrm{p}=0,006 \mathrm{y}$ $0,009)$. Los biovolumenes no fueron estadísticamente diferentes entre las tres áreas $(\mathrm{p}=0,089)$ y estuvieron en el rango de biomasa media para las tres (Figura 4, Tabla 3).

\section{Zooplankton biomass}

Zooplankton biovolume oscillated between 24.7 and $455.6 \mathrm{ml} / 1000 \mathrm{~m}^{3}$. The biovolume for Malpelo was normally distributed $(p=0.115)$, but this was not the case for Sanquianga and Gorgona ( $p=0.006$ and 0.009). The biovolumes did not differ statistically between the three areas $(\mathrm{p}=0.089)$, lying within the average biomass range in all three areas (Figure 4. Table 3).
Tabla 3. Biovolumen del zooplancton en el PNN Sanquianga, PNN Gorgona y SFF Malpelo, Pacífico colombiano, durante noviembre de 2009.
Table 3. Biovolume of zooplankton in the Sanquianga and Gorgona NNPs and the Malpelo FFS, Colombian Pacific, November 2009.

\begin{tabular}{|c|c|c|c|c|}
\hline Áreas / Location & B Min $\left(\mathbf{m l} / \mathbf{1 0 0 0 \mathbf { m } ^ { \mathbf { 3 } } )}\right.$ & B Max $\left(\mathbf{m l} / \mathbf{1 0 0 0 \mathbf { m } ^ { \mathbf { 3 } } )}\right.$ & Media $\left(\mathbf{m l} / \mathbf{1 0 0 0 \mathbf { m } ^ { \mathbf { 3 } } )}\right.$ & N $($ Estaciones $) /($ Stations $)$ \\
\hline Sanquianga & 28.07 & 455.6 & 179.9 & 24 \\
Gorgona & 24.7 & 389.7 & 121.2 & 24 \\
Malpelo & 45.8 & 337.8 & 197.9 & 12 \\
\hline
\end{tabular}




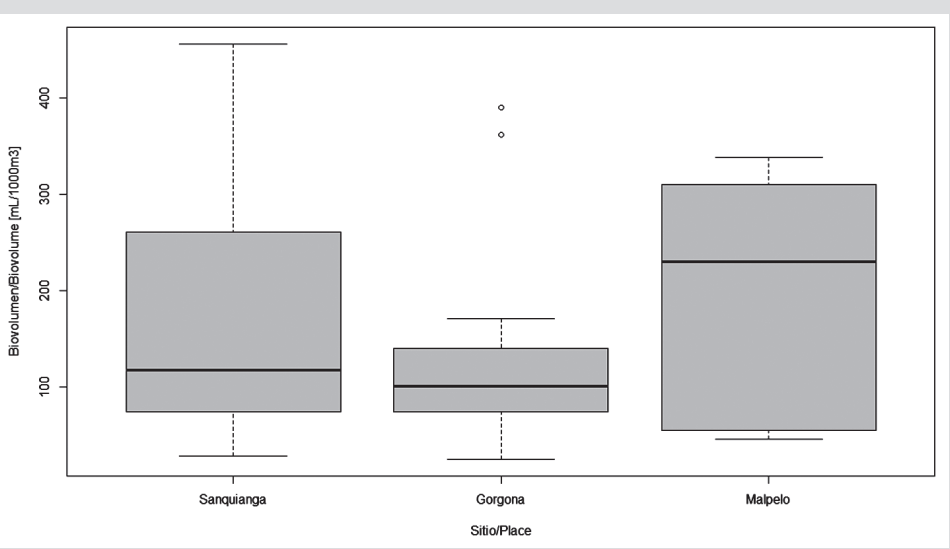

Figura 4. Biovolumen zooplanctónico $\left(\mathrm{ml} / 1000 \mathrm{~m}^{3}\right)$ en el PNN Sanquianga, PNN Gorgona y SFF Malpelo, Pacífico colombiano, durante noviembre de 2009 .
Figure 4. Zooplanktonic biovolume $\left(\mathrm{ml} / 1000 \mathrm{~m}^{3}\right)$ in the Sanquianga and Gorgona NNPs and the Malpelo FFS, Colombian Pacific, November 2009 .

\section{Huevos de peces}

Se recolectaron en total 17341 huevos $/ 10 \mathrm{~m}^{2}$, de los cuales 6603 huevos $/ 10 \mathrm{~m}^{2}$ pertenecen al PNN Sanquianga, 10256 huevos $/ 10 \mathrm{~m}^{2}$ al PNN Gorgona y 482 huevos $/ 10 \mathrm{~m}^{2}$ al SFF Malpelo. Los huevos de peces no presentaron una distribución normal en ninguna de las tres áreas protegidas ( $\mathrm{p}<0,009)$, no se rechaza el supuesto de homocedasticidad $(\mathrm{p}=0,063)$. No presentaron diferencias significativas $(\mathrm{p}=0,73)$; entre las tres áreas. Se apreciaron valores más altos en Gorgona, seguidos de Sanquianga y Malpelo (Figura 5, Tabla 4). 62,50 \% de las estaciones en Sanquianga, 70,83\% en Gorgona y 85,00 \% en Malpelo presentaron abundancias bajas de huevos.

La abundancia total de huevos de la familia Engraulidae fue de 9312 huevos $/ 10 \mathrm{~m}^{2}$, de los cuales la mayor abundancia ( 8586 huevos $/ 10 \mathrm{~m}^{2}$ ) se presentó en la estación 17 noroeste del PNN Gorgona. Estos huevos no presentaron una distribución normal en ninguna de las tres áreas y se rechaza el supuesto de homocedasticidad ( $\mathrm{p}<0,001)$. Las diferencias en el conteo de huevos de Engraulidae entre las tres áreas fueron significativas $(\mathrm{P}=0,001)$, siendo mayor la abundancia en Gorgona, seguido de Sanquianga y menor en Malpelo.

Tabla 4. Abundancia de huevos $(\mathrm{H})$ y larvas de peces (L) en el PNN Sanquianga, PNN Gorgona y SFF Malpelo, Pacífico colombiano, durante noviembre de 2009.
Fish eggs

A total of 17,341 eggs $/ 10 \mathrm{~m}^{2}$ were collected, of which $6,603 \mathrm{eggs} / 10 \mathrm{~m}^{2}$ came from the Sanquianga NNP, 10,256 eggs $/ 10 \mathrm{~m}^{2}$ from the Gorgona NNP and 482 eggs $/ 10 \mathrm{~m}^{2}$ from the Malpelo FFS. Fish egg numbers were not normally distributed in any of the three protected areas $(p<0.009)$ and the homoscedasticity assumption was not rejected $(p=0.063)$. No significant differences were found between the three areas $(\mathrm{p}=0.73)$. Values were highest in Gorgona, followed by Sanquianga and Malpelo (Figure 5, Table 4). Low abundance levels were reported for fish eggs in $62.50 \%$ of the stations in Sanquianga, $70.83 \%$ of those in Gorgona and $85.00 \%$ in Malpelo.

Total abundance of eggs from the family Engraulidae was 9,312 eggs $/ 10 \mathrm{~m}^{2}$, of which the greatest abundance $(8,586$ eggs $/ 10 \mathrm{~m}^{2}$ ) was found at station 17 , northeast of the Gorgona NNP. The number of eggs per station were not normally distributed in any of the three areas, and the homoscedasticity assumption was rejected $(p<0.001)$. The differences in the Engraulidae egg count between the three areas were significant $(\mathrm{P}=0.001)$, the greatest abundance being found in Gorgona, followed by Sanquianga and, lastly, Malpelo.

Table 4. Abundance of eggs $(\mathrm{H})$ and fish larvae $(\mathrm{L})$ in the Sanquianga and Gorgona NNPs and the Malpelo FFS, Colombian Pacific, November 2009.

\begin{tabular}{|c|c|c|c|c|c|c|c|}
\hline Áreas / Location & $\begin{array}{c}\mathrm{H} \mathrm{Min} \\
\left.\text { (ind/10m }{ }^{2}\right)\end{array}$ & $\begin{array}{c}\text { H Max } \\
\text { (ind/10m²) }\end{array}$ & $\begin{array}{c}\text { Promedio / } \\
\text { Average (ind } / 10 \mathrm{~m}^{2} \text { ) }\end{array}$ & $\begin{array}{c}\mathrm{L} \text { Min } \\
\text { (ind } / \mathbf{1 0 \mathrm { m } ^ { 2 }} \text { ) }\end{array}$ & $\begin{array}{c}\text { L Max } \\
\text { (ind/10m }{ }^{2} \text { ) }\end{array}$ & $\begin{array}{c}\text { Promedio / } \\
\text { Average (ind } / 10 \mathrm{~m}^{2} \text { ) }\end{array}$ & $\begin{array}{c}\text { N (Estaciones) / } \\
\text { (Stations) }\end{array}$ \\
\hline Sanquianga & 0 & 2519 & 275 & 0 & 891 & 64 & 24 \\
\hline Gorgona & 0 & 8586 & 427 & 5 & 159 & 59 & 24 \\
\hline Malpelo & 0 & 170 & 40 & 1 & 44 & 16 & 12 \\
\hline
\end{tabular}




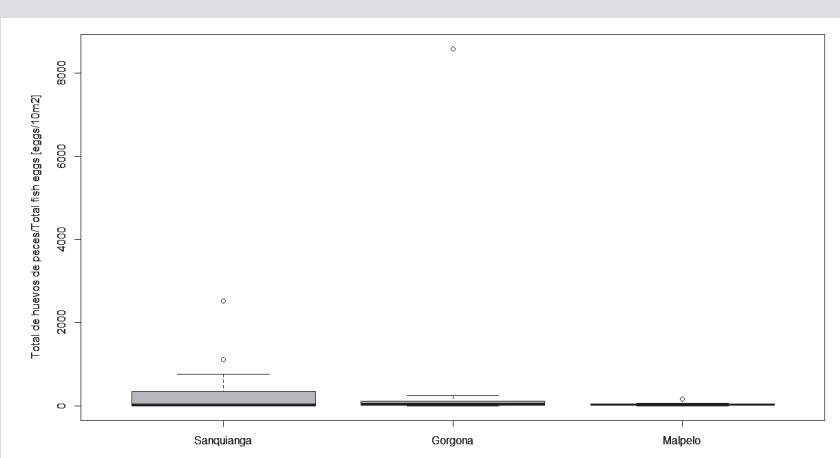

Figura 5. Abundancia de huevos de peces (izquierda) y abundancia de larvas de peces (derecha) (ind $/ 10 \mathrm{~m}^{2}$ ) en el PNN Sanquianga, PNN Gorgona y SFF Malpelo, Pacífico colombiano, durante noviembre de 2009.

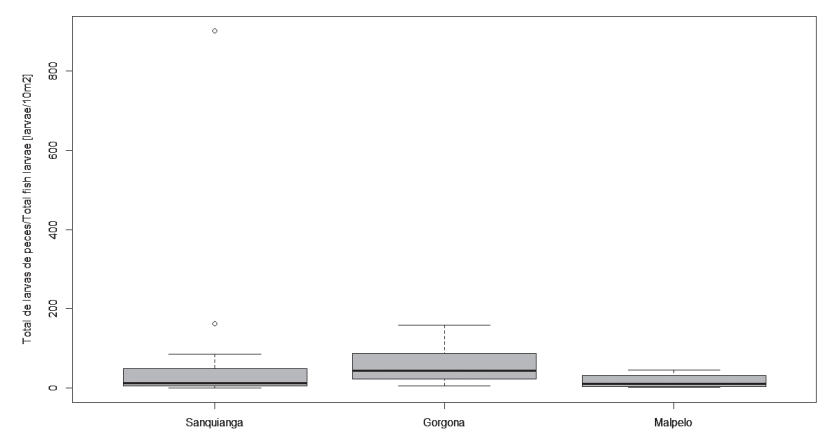

Figure 5. Abundance of fish eggs (left) and of fish larvae (right) (ind $/ 10 \mathrm{~m}^{2}$ ) in the Sanquianga and Gorgona NNPs and Malpelo FFS, Colombian Pacific, November 2009.

\section{Larvas de peces}

Se recolectaron en total 3155 larvas $/ 10 \mathrm{~m}^{2}$, de las que 1553 larvas/10 $\mathrm{m}^{2}(49,22 \%)$ pertenecen al PNN Sanquianga, 1411 larvas/10 $\mathrm{m}^{2}(44,72 \%)$ al PNN Gorgona y 191 larvas/10 m² (6,05\%) al SFF Malpelo. Las larvas de peces para Gorgona y Malpelo pueden ser consideradas con distribución normal $(\mathrm{p}=0,045$ y 0,093$)$, pero para Sanquianga no $(\mathrm{p}<0,001)$. Con la homocedasticidad encontrada se hallaron diferencias significativas entre las tres áreas $(\mathrm{p}=0,001)$. Fueron más abundantes en Gorgona que en Sanquianga y Malpelo ( $p=0,008$ y 0,003 ), pero entre Sanquianga y Malpelo no hay diferencias significativas $(\mathrm{p}=0,512)$ (Figura 5, Tabla 4). 91,67\% de las estaciones en Sanquianga, $79 \%$ en Gorgona, y $95 \%$ en Malpelo presentaron abundancias bajas de larvas de peces.

Larvas de la familia Engraulidae no se encontraron en Malpelo. Ni Gorgona ni Sanquianga muestran distribución normal en la cantidad de larvas, de acuerdo con el gráfico QQ-plot, y el test de Shapiro-Wilk ( $<<0,001)$. Se encontraron diferencias significativas en la cantidad de larvas de engráulidos entre Sanquianga y Gorgona $(p=0,022)$. En promedio es mayor la cantidad de larvas en Sanquianga que en Gorgona.

\section{Composición de las capturas}

Durante noviembre de 2009 se identificaron para las tres áreas protegidas 42 familias, 65 géneros y 90 especies, de las cuales 16 familias (38,10\%), 21 géneros $(32,31 \%)$ y 32 especies (35,56\%) fueron de Sanquianga; 29 familias $(69,05 \%), 38$ géneros $(58,46 \%)$ y 52 especies $(57,78 \%)$ fueron de Gorgona; y 12 familias $(28,57 \%), 19$ géneros $(29,23 \%)$ y 21 especies $(23,33 \%)$, de Malpelo. (Tabla 5). Las mayores abundancias en el PNN Sanquianga las presentaron las familias Engraulidae (anchoas) (64,39 \%),
Fish larvae

A total of 3,155 larvae $/ 10 \mathrm{~m}^{2}$ were collected, of which 1,553 larvae/10 $\mathrm{m}^{2}(49.22 \%)$ came from the Sanquianga NNP, 1,411 larvae/10 $\mathrm{m}^{2}(44.72 \%)$ from the Gorgona NNP and 191 larvae/10 $\mathrm{m}^{2}(6.05 \%)$ from the Malpelo FFS. The distribution of fish larvae in Gorgona and Malpelo may be considered normal $(p=0.045$ and 0.093$)$, but not in Sanquianga $(p<0.001)$. Significant differences were found between the two areas in terms of homoscedasticity $(p=0.001)$. Larvae were more abundant in Gorgona than in Sanquianga and Malpelo ( $p=0.008$ and 0.003 ), but there were no significant differences between Sanquianga and Malpelo ( $p=0.512$ ) (Figure 5, Table 4). Overall, $9.17 \%$ of the stations in Sanquianga, $79 \%$ in Gorgona and $95 \%$ in Malpelo presented low fish larvae abundance.

Larvae of Engraulidae were not found in Malpelo. According to the QQ plot graph and Shapiro-Wilk test $(p<0.001)$, the distribution of the number of larvae was not normal in either Gorgona or Sanquianga. There were significant differences in the numbers of Engraulidae larvae found in Sanquianga and Gorgona $(\mathrm{p}=0.022)$. On average, more larvae were found in Sanquianga than in Gorgona.

\section{Composition of the catch}

A total of 42 families, 65 genera and 90 species were found in the three protected areas in November 2009, of which 16 families (38.10\%), 21 genera (32.31\%) and 32 species $(35.56 \%)$ were found in Sanquianga; 29 families $(69.05 \%), 38$ genera $(58.46 \%)$ and 52 species $(57.78 \%)$ in Gorgona; and 12 families (28.57\%), 19 genera (29.23\%) and 21 species (23.33\%) in Malpelo (Table 5). The most abundant families found in the Sanquianga NNP were Engraulidae (anchovies) (64.39\%), Sciaenidae (croakers) (13.39), Gobiidae (gobies) (9.53\%), Haemulidae (grunts) 
Sciaenidae (peladas) $(13,39)$, Gobiidae (sapitos) $(9,53 \%)$, Haemulidae (pargos blancos) $(6,12 \%)$ y 12 familias más que componen $6,37 \%$ restante; $0,19 \%$ corresponde a larvas vitelinas sin clasificar (Tabla 5, Figura 6).

Para el PNN Gorgona las familias Bregmacerotidae (merlucitas) (17,65 \%), Gobiidae (sapitos) (13,11\%), Sciaenidae (peladas) (10,28 \%), Haemulidae (pargos blancos) $(9,85 \%)$, Trichiuridae (peces cinta) $(5,95 \%)$, Paralichthyidae (lenguados) (5,74 \%), Engraulidae (anchoas) (3,97 \%), Cynoglossidae (peces lengüeta) (3,05\%), Serranidae (chernas) $(2,98 \%)$ y 20 familias más que componen el 19,92\% restante; el 4,89\% corresponde a larvas vitelinas y $2.62 \%$ a otros (Tabla 5 , Figura7). Para el SFF Malpelo las familias Phosichthyidae (peces linterna) (48,69 \%), Gobiidae (sapitos) (13,11\%), Myctophidae (peces linterna) (25,65\%), Hemiramphidae (mediopicos) (11,52\%), Pomacentridae (repeladores) $(3,66 \%)$ y ocho familias más que componen $8,90 \% ; 1,57 \%$ corresponde a otros (Tabla 5, Figura 8).

De las 42 familias identificadas 14,29 \% (Engraulidae, Serranidae, Carangidae, Haemulidae, Sciaenidae y Gobiidae) están presentes tanto en Sanquianga como en Gorgona, 11,90 \% (Paralepididae, Coryphaenidae, Pomacentridae, Paralichthyidae y Tetraodontidae) presentes en Gorgona y Malpelo, el 4,76 \% (Phosichthyidae y Hemiramphidae) presentes en Sanquianga y Malpelo y el 2,38 \% (Myctophidae) están presentes en las tres áreas protegidas. Mientras $16,67 \%$, compuesto por las familias Pristigasteridae, Clupeidae, Belonidae, Gobiesocidae,
$(6.12 \%)$ and 12 further families that made up the remaining $6.37 \% .0 .19 \%$ of the samples consisted of un-classified yolk-sac larvae (Table 5, Figure 6).

For the Gorgona NNP the samples consisted of the families Bregmacerotidae (codlets) (17.65\%), Gobiidae (gobies) (13.11\%), Sciaenidae (croakers) (10.28\%), Haemulidae (grunts) $(9.85 \%)$, Trichiuridae (cutlass fish) (5.95\%), Paralichthyidae (flounders) (5.74\%), Engraulidae (anchovies) (3.97\%), Cynoglossidae (tonguefishes) (3.05\%), Serranidae (seabasses) (2,98 \%) and 20 further families that accounted for $19.92 \%$ of the total abundance. $4.89 \%$ consisted of unclassified yolk-sac larvae and $2.62 \%$ was classified as others (Table 5, Figure7). For the Malpelo FFS the catch consisted of the families Phosichthyidae (lightfish) (48.69 \%), Gobiidae (gobies) (13.11 \%), Myctophidae (lanternfish) (25.65\%), Hemiramphidae (halfbeaks) (11.52 \%), Pomacentridae (damselfish) (3.66 \%) and eight further families that accounted for $8.90 \%$ of the total abundance. Others accounted for $1.57 \%$ (Table 5, Figure 8).

Of the 42 families identified, 14.29\% (Engraulidae, Serranidae, Carangidae, Haemulidae, Sciaenidae and Gobiidae) were present both in Sanquianga and in Gorgona, $11.90 \%$ (Paralepididae, Coryphaenidae, Pomacentridae, Paralichthyidae and Tetraodontidae) in Gorgona and Malpelo, $4.76 \%$ (Phosichthyidae and Hemiramphidae) in Sanquianga and Malpelo and $2.38 \%$ (Myctophidae) in all three protected areas. While $16.67 \%$, of the total -the families Pristigasteridae, Clupeidae, Belonidae, Gobiesocidae, Eleotridae, Scombridae and Achiridae-

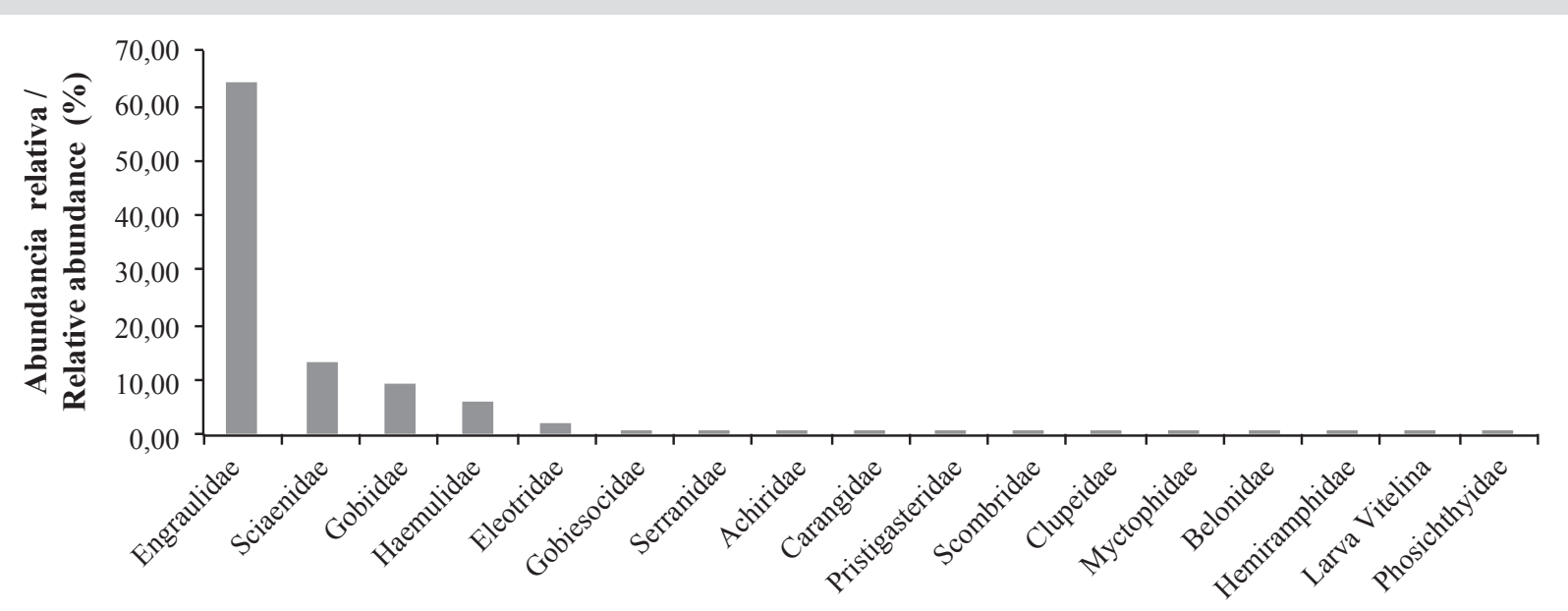

Familias / Families SFF Saquianga

Figura 6. Abundancia relativa (\%) de familias en el PNN Sanquianga, durante noviembre 2009.
Figure 6. Relative abundance (\%) of families in the Sanquianga NNP, during November 2009. 
Eleotridae, Scombridae y Achiridae fueron exclusivas para el PNN Sanquianga; 40,48 \%, familias Aulopidae, Synodontidae, Ophidiidae, Bythitidae, Bregmacerotidae, Merlucciidae, Mugilidae, Melamphaidae, Scorpaenidae, Gerreidae, Mullidae, Labridae, Tripterygiidae, Blenniidae, Microdesmidae, Trichiuridae y Cynoglossidae, fueron exclusivas del PNN Gorgona; 9,52 \%, familias Gonostomatidae, Exocoetidae, Lutjanidae y Nomeidae fueron exclusivas para el SFF Malpelo (Tabla 5). were found exclusively in the Sanquianga NNP, $40.48 \%$ (the families Aulopidae, Synodontidae, Ophidiidae, Bythitidae, Bregmacerotidae, Merlucciidae, Mugilidae, Melamphaidae, Scorpaenidae, Gerreidae, Mullidae, Labridae, Tripterygiidae, Blenniidae, Microdesmidae, Trichiuridae and Cynoglossidae) were found exclusively in the Gorgona NNP; and $9.52 \%$-the Gonostomatidae, Exocoetidae, Lutjanidae and Nomeidae- were exclusive to the Malpelo FFS (Table 5).

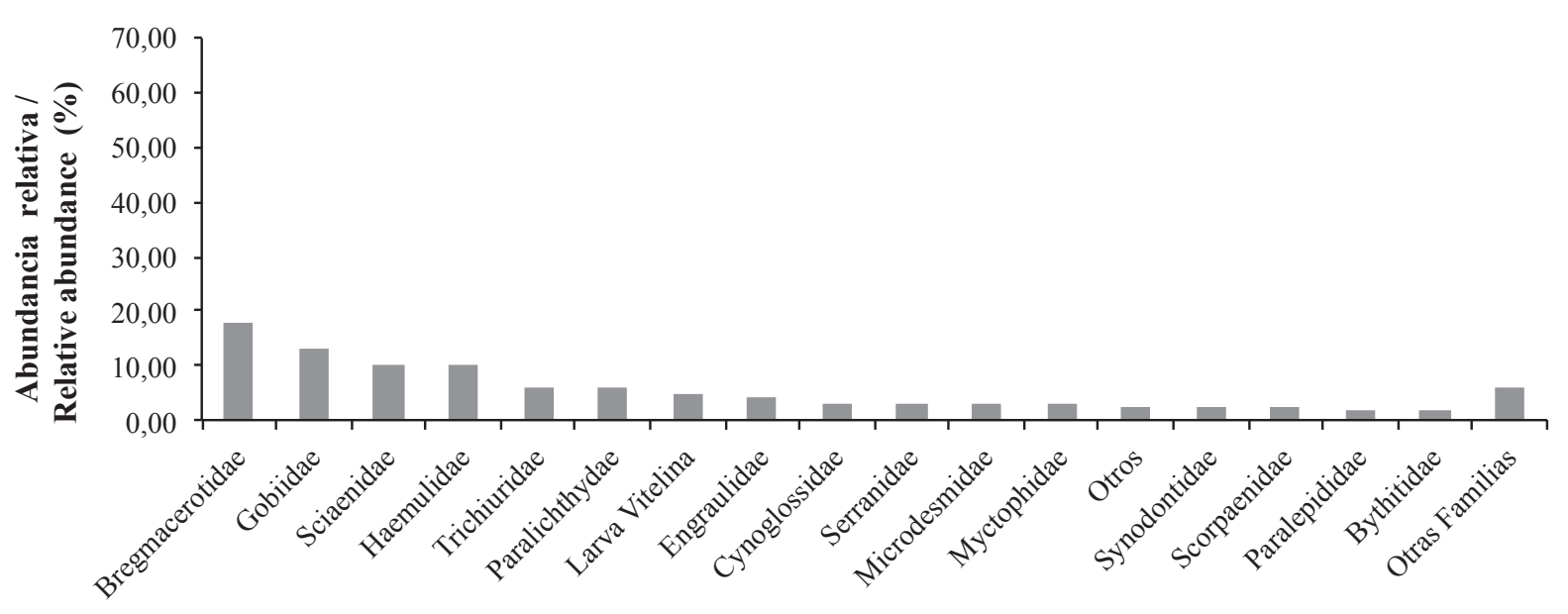

Familias / Families SFF Gorgona

Figura 7. Abundancia relativa (\%) de familias en el PNN Gorgona, durante noviembre 2009.
Figure 7. Relative abundance (\%) of families in the Gorgona NNP during November 2009.

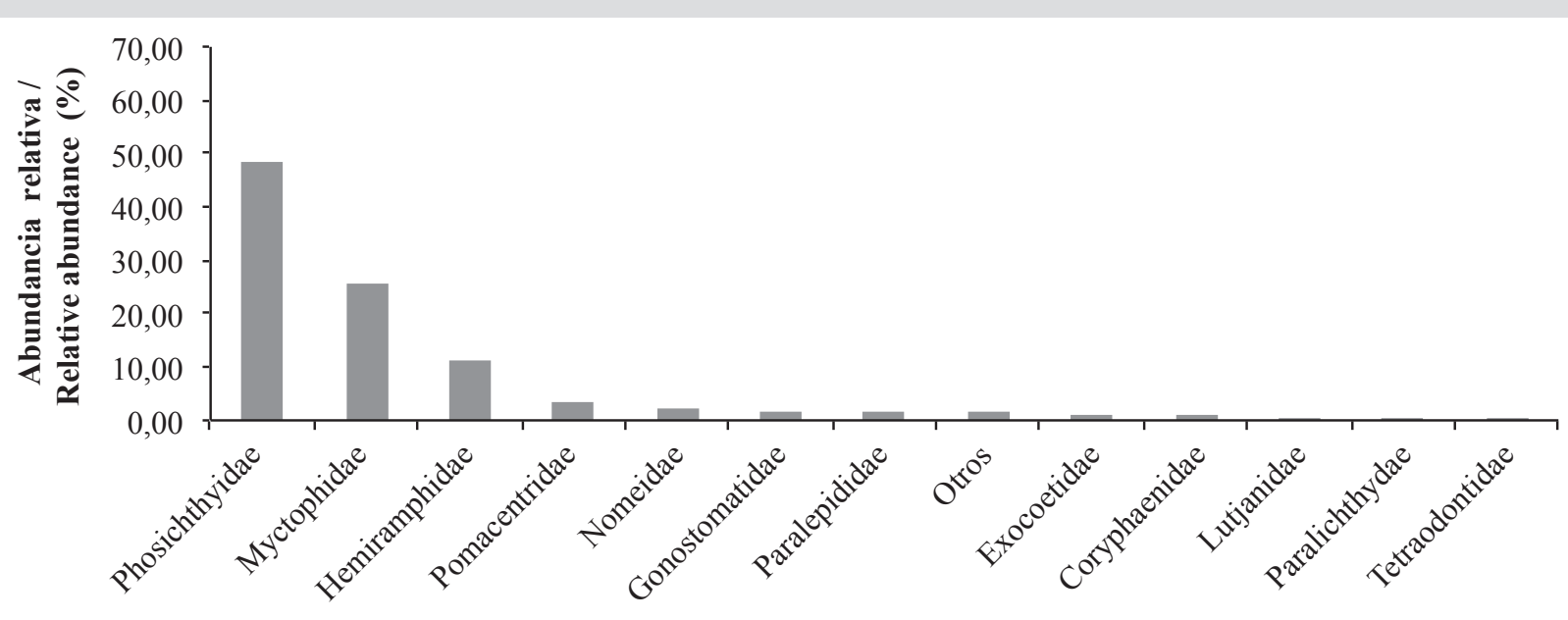

Familias / Families SFF Malpelo

Figura 8. Abundancia relativa (\%) de familias en el SFF Malpelo, durante noviembre 2009.
Figure 8. Relative abundance (\%) of families in the Malpelo FFS, during November 2009. 
Tabla 5. Composición y abundancia relativa (\%) de las larvas de peces presentes en el PNN Sanquianga, PNN Gorgona y SFF Malpelo, Pacífico colombiano, durante noviembre de 2009
Table 5. Composition and relative abundance (\%) of fish larvae present in the Sanquianga and Gorgona NNPs and Malpelo FFS, Colombian Pacific, November 2009.

\begin{tabular}{|c|c|c|c|c|c|c|}
\hline \multirow{2}{*}{ Familia - Especie / Family - Species } & \multicolumn{2}{|c|}{ PNN Sanquianga } & \multicolumn{2}{|c|}{ PNN Gorgona } & \multicolumn{2}{|c|}{ SFF Malpelo } \\
\hline & Total & $(\%)$ & Total & $(\%)$ & Total & $(\%)$ \\
\hline \multicolumn{7}{|l|}{ Engraulidae } \\
\hline Anchoa sp. 1 & 4 & 0.26 & & & & \\
\hline Anchovia macrolepidota & 61 & 3.93 & & & & \\
\hline Cetengraulis mysticetus & 935 & 60.21 & 56 & 3.97 & & \\
\hline \multicolumn{7}{|l|}{ Pristigasteridae } \\
\hline Opisthopterus effulgens & 4 & 0.26 & & & & \\
\hline \multicolumn{7}{|l|}{ Clupeidae } \\
\hline Opisthonema sp. & 3 & 0.19 & & & & \\
\hline \multicolumn{7}{|l|}{ Gonostomatidae } \\
\hline Cyclothone sp. & & & & & 2 & 1.05 \\
\hline Cyclothone signatha & & & & & 1 & 0.52 \\
\hline \multicolumn{7}{|l|}{ Phosichthyidae } \\
\hline Vinciguerria lucetia & & & & & 93 & 48.69 \\
\hline Woodsia sp. & 2 & 0.13 & & & & \\
\hline \multicolumn{7}{|l|}{ Aulopodidae } \\
\hline Aulopus bajacali & & & 8 & 0.57 & & \\
\hline \multicolumn{7}{|l|}{ Synodontidae } \\
\hline Synodus evermanni & & & 1 & 0.07 & & \\
\hline Synodus scituliceps & & & 17 & 1.20 & & \\
\hline Synodus spp. & & & 15 & 1.06 & & \\
\hline \multicolumn{7}{|l|}{ Paralepididae } \\
\hline Lestidiops neles & & & & & 3 & 1.57 \\
\hline Lestidiops pacificus & & & 23 & 1.63 & & \\
\hline \multicolumn{7}{|l|}{ Myctophidae } \\
\hline Benthosema panamense & & & & & 3 & 1.57 \\
\hline Diaphus pacificus & & & & & 4 & 2.09 \\
\hline Diogenichthys laternatus & & & 31 & 2.20 & 4 & 2.09 \\
\hline Lampanyctus parvicauda & & & 6 & 0.43 & 18 & 9.42 \\
\hline Lampanyctus tenuiformes & & & & & 5 & 2.62 \\
\hline Myctophum aurolaternatum & 3 & 0.19 & & & & \\
\hline Myctophum sp1. & & & 3 & 0.21 & & \\
\hline Nannobrachium sp. & & & & & 13 & 6.81 \\
\hline Symbolophorus evermanni & & & & & 2 & 1.05 \\
\hline \multicolumn{7}{|l|}{ Ophidiidae } \\
\hline Lepophidium sp. & & & 12 & 0.85 & & \\
\hline
\end{tabular}




\begin{tabular}{|c|c|c|c|c|c|c|}
\hline \multirow{2}{*}{ Familia - Especie / Family - Species } & \multicolumn{2}{|c|}{ PNN Sanquianga } & \multicolumn{2}{|c|}{ PNN Gorgona } & \multicolumn{2}{|c|}{ SFF Malpelo } \\
\hline & Total & $(\%)$ & Total & $(\%)$ & Total & $(\%)$ \\
\hline \multicolumn{7}{|l|}{ Bythitidae } \\
\hline Cataetyx cf. simus & & & 23 & 1.63 & & \\
\hline \multicolumn{7}{|l|}{ Bregmacerotidae } \\
\hline Bregmaceros bathymaster & & & 249 & 17.65 & & \\
\hline \multicolumn{7}{|l|}{ Merlucciidae } \\
\hline Merluccius angustimanus & & & 3 & 0.21 & & \\
\hline \multicolumn{7}{|l|}{ Mugilidae } \\
\hline Mugil curema & & & 3 & 0.21 & & \\
\hline \multicolumn{7}{|l|}{ Belonidae } \\
\hline Strongylura scapularis & 3 & 0.19 & & & & \\
\hline \multicolumn{7}{|l|}{ Exocoetidae } \\
\hline Cheilopogon sp. & & & & & 2 & 1.05 \\
\hline \multicolumn{7}{|l|}{ Hemiramphidae } \\
\hline Hyporhamphus sp. & 3 & 0.19 & & & 21 & 10.99 \\
\hline Oxyporhamphus micropterus & & & & & 1 & 0.52 \\
\hline \multicolumn{7}{|l|}{ Melamphaidae } \\
\hline Melamphaes sp. 2 & & & 9 & 0.64 & & \\
\hline \multicolumn{7}{|l|}{ Scorpaenidae } \\
\hline Scorpaena guttata & & & 17 & 1.20 & & \\
\hline Scorpaenidae sp. & & & 15 & 1.06 & & \\
\hline \multicolumn{7}{|l|}{ Serranidae } \\
\hline Paralabrax sp.1 & 13 & 0.84 & & & & \\
\hline Serranus sp.1 & & & 8 & 0.57 & & \\
\hline Serranus sp. 3 & & & 34 & 2.41 & & \\
\hline \multicolumn{7}{|l|}{ Coryphaenidae } \\
\hline Coryphaena hippurus & & & 8 & 0.57 & 2 & 1.05 \\
\hline \multicolumn{7}{|l|}{ Carangidae } \\
\hline Alectis ciliaris & & & 3 & 0.21 & & \\
\hline Selar crumenophthalmus & & & 6 & 0.43 & & \\
\hline Seriola lalandi & 4 & 0.26 & & & & \\
\hline Seriola sp. & 1 & 0.06 & & & & \\
\hline \multicolumn{7}{|l|}{ Lutjanidae } \\
\hline Hoplopagrus guentherii & & & & & 1 & 0.52 \\
\hline \multicolumn{7}{|l|}{ Gerreidae } \\
\hline Eucinostomus sp. & & & 10 & 0.71 & & \\
\hline
\end{tabular}




\begin{tabular}{|c|c|c|c|c|c|c|}
\hline \multirow{2}{*}{ Familia - Especie / Family - Species } & \multicolumn{2}{|c|}{ PNN Sanquianga } & \multicolumn{2}{|c|}{ PNN Gorgona } & \multicolumn{2}{|c|}{ SFF Malpelo } \\
\hline & Total & $(\%)$ & Total & $(\%)$ & Total & $(\%)$ \\
\hline \multicolumn{7}{|l|}{ Haemulidae } \\
\hline Haemulidae sp.1 & 62 & 3.99 & 40 & 2.38 & & \\
\hline Haemulidae sp.2 & & & 38 & 2.69 & & \\
\hline Haemulidae spp. & 33 & 2.12 & 61 & 4.32 & & \\
\hline \multicolumn{7}{|l|}{ Sciaenidae } \\
\hline Bairdiella spp. & & & 2 & 0.14 & & \\
\hline Isopisthus remifer & & & 2 & 0.14 & & \\
\hline Larimus sp.1 & & & 81 & 5.74 & & \\
\hline Larimus sp. 3 & 48 & 3.09 & & & & \\
\hline Menticirrhus sp. & 3 & 0.19 & & & & \\
\hline Stellifer $\mathrm{sp} .2$ & 6 & 0.39 & & & & \\
\hline Stellifer $\mathrm{sp.} 3$ & 8 & 0.52 & 15 & 1.06 & & \\
\hline Sciaenidae spp. & 143 & 9.21 & 45 & 3.19 & & \\
\hline \multicolumn{7}{|l|}{ Mullidae } \\
\hline Mullidae sp. & & & 2 & 0.14 & & \\
\hline \multicolumn{7}{|l|}{ Pomacentridae } \\
\hline Abudefduf troschelii & & & & & 4 & 2.09 \\
\hline Azurina atrilobata & & & 1 & 0.07 & 3 & 1.57 \\
\hline Stegastes spp. & & & 5 & 0.35 & & \\
\hline \multicolumn{7}{|l|}{ Labridae } \\
\hline Halichoeres spp. & & & 3 & 0.21 & & \\
\hline \multicolumn{7}{|l|}{ Tripterygiidae } \\
\hline Axoclinus lucillae & & & 5 & 0.35 & & \\
\hline \multicolumn{7}{|l|}{ Blenniidae } \\
\hline Hypsoblennius brevipinnis & & & 6 & 0.43 & & \\
\hline \multicolumn{7}{|l|}{ Gobiesocidae } \\
\hline Gobiesox sp.2 & 2 & 0.13 & & & & \\
\hline Gobiesox sp.3 & 5 & 0.32 & & & & \\
\hline Gobiesocidae sp. & 8 & 0.52 & & & & \\
\hline \multicolumn{7}{|l|}{ Eleotridae } \\
\hline Dormitator latifrons & 38 & 2.45 & & & & \\
\hline \multicolumn{7}{|l|}{ Gobiidae } \\
\hline Microgobius sp. & 17 & 1.09 & & & & \\
\hline Lythrypnus sp. & & & 3 & 0.21 & & \\
\hline Gobiidae sp. 1 & 16 & 1.03 & 37 & 2.62 & & \\
\hline Gobiidae sp. 2 & & & 10 & 0.71 & & \\
\hline Gobiidae sp.3 & 48 & 3.09 & 10 & 0.71 & & \\
\hline Gobiidae sp.4 & 27 & 1.74 & 85 & 6.02 & & \\
\hline Gobiidae sp.7 & 18 & 1.16 & & & & \\
\hline Gobiidae spp. & 22 & 1.42 & 40 & 2.38 & & \\
\hline
\end{tabular}




\begin{tabular}{|c|c|c|c|c|c|c|}
\hline \multirow{2}{*}{ Familia - Especie / Family - Species } & \multicolumn{2}{|c|}{ PNN Sanquianga } & \multicolumn{2}{|c|}{ PNN Gorgona } & \multicolumn{2}{|c|}{ SFF Malpelo } \\
\hline & Total & $(\%)$ & Total & $(\%)$ & Total & $(\%)$ \\
\hline \multicolumn{7}{|l|}{ Microdesmidae } \\
\hline Clarkichthys bilineatus & & & 40 & 2.83 & & \\
\hline Gunnellichthys sp. & & & 2 & 0.14 & & \\
\hline \multicolumn{7}{|l|}{ Trichiuridae } \\
\hline Trichiurus nitens & & & 84 & 5.95 & & \\
\hline \multicolumn{7}{|l|}{ Scombridae } \\
\hline Auxis sp.1 & 4 & 0.26 & & & & \\
\hline \multicolumn{7}{|l|}{ Nomeidae } \\
\hline Cubiceps pauciradiatus & & & & & 4 & 2.09 \\
\hline \multicolumn{7}{|l|}{ Paralichthyidae } \\
\hline Citharichthys gilberti & & & 73 & 5.17 & & \\
\hline Citharichthys sp. & & & 8 & 0.57 & & \\
\hline Syacium ovale & & & & & 1 & 0.52 \\
\hline \multicolumn{7}{|l|}{ Achiridae } \\
\hline Achirus kluzingueri & 4 & 0.26 & & & & \\
\hline Achirus mazatlanus & 2 & 0.13 & & & & \\
\hline \multicolumn{7}{|l|}{ Cynoglossidae } \\
\hline Symphurus chabanaudi & & & 8 & 0.57 & & \\
\hline Symphurus sp. & & & 35 & 2.48 & & \\
\hline \multicolumn{7}{|l|}{ Tetraodontidae } \\
\hline Sphoeroides annulatus & & & 1 & 0.07 & & \\
\hline Sphoeroides lobatus & & & 3 & 0.21 & 1 & 0.52 \\
\hline Larva Vitelinas & 3 & 0.19 & 69 & 4.89 & & \\
\hline Otros & & & 37 & 2.62 & 3 & 1.57 \\
\hline TOTAL & 1553 & 100 & 1411 & 100 & 191 & 100 \\
\hline
\end{tabular}

El análisis de ordenación fue muy consistente, se observan diferencias (evidenciada por la distancia de los puntos) de la riqueza y composición de especies separando las áreas en tres grupos: PNN Sanquianga ubicada en la zona costera (asociada al eje 1, separada de Malpelo por salinidad y temperatura y de Gorgona por salinidad), Gorgona en la zona intermedia (asociada también al eje 1, separada de Malpelo por temperatura y de Sanquianga por salinidad) y Malpelo en la zona oceánica (asociada al eje 2, separada de Sanquianga por salinidad y temperatura y de Gorgona por temperatura). Resulta evidente la clara separación en la distribución de los puntos en los sitios por área, lo que respalda la ubicación de las áreas en las zonas costera, intermedia y oceánica (Figura 9).
The ordination analysis was very consistent, differences (evidenced by distance from the points) were observed in the richness and composition of species by separating the area into three groups: the Sanquianga NNP located in the coastal area (associated with axis 1, differentiated from Malpelo by salinity and temperature and from Gorgona by salinity), Gorgona in the intermediate zone (also associated with axis 1 and differentiated from Malpelo by temperature and from Sanquianga by salinity) and Malpelo, in the oceanic zone (associated with axis 2, differentiated from Sanquianga by salinity and temperature and from Gorgona by temperature). The clear differentiation between the distribution of the points in the localities by area is evident, a finding that supports the decision to separate the areas into the costal, intermediate and oceanic zones (Figure 9). 


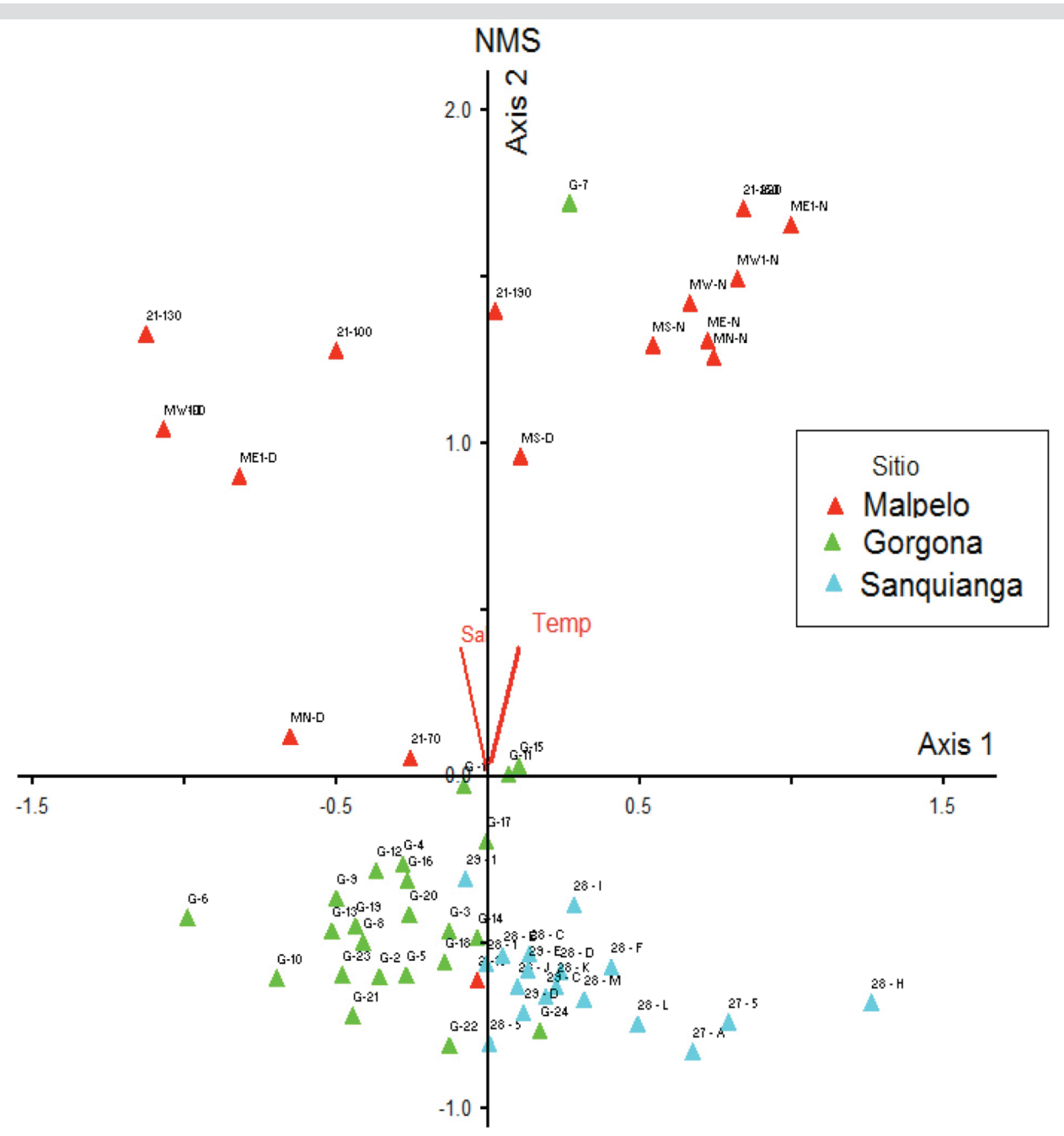

ANÁLISIS NMS (Escalamiento Multidimensional No Métrico)

Figura 9. Análisis NMS sitio 1 rojo (SFF Malpelo), sitio 2 verde (PNN Gorgona) y sitio 3 azul (PNN Sanquianga), noviembre 2009.
Figure 9. NMS analysis of site 1 red (Malpelo FFS), site 2 green (Gorgona NNP) and site 3 blue (Sanquianga NNP), November 2009.
El área protegida del PNN Sanquianga, ubicada en la zona costera, presentó la mayor abundancia dominada por la especie Cetengraulis mysticetus con 935 larvas/10 $\mathrm{m}^{2}$ (60,21\%). El PNN Gorgona presentó una abundancia menor, dominada por la especie Bregmaceros bathymaster con 249 larvas $/ 10 \mathrm{~m}^{2}$ (17,65\%). El SFF Malpelo ubicado en la zona oceánica, mostró una abundancia muy baja de larvas de peces en comparación con las otras áreas, dominada por la especie Vinciguerria lucetia 93 larvas/10 m² (48,69\%). Para noviembre de 2009 se encontraron huevos de la familia Engraulidae en el PNN Gorgona, lo cual puede ser normal; sin embargo, no lo es con un valor de muy alta abundancia. De igual manera, resulta sorpresivo haber encontrado huevos de esta familia en los alrededores de Malpelo, de noche al occidente y en el día al sur.
Sanquianga NNP, located in the coastal zone, had the greatest species abundance, dominated by Cetengraulis mysticetus, with 935 larvae/10 $\mathrm{m}^{2}(60.21 \%)$. The Gorgona NNP had lower abundance levels and was dominated by Bregmaceros bathymaster, with 249 larvae/10 $\mathrm{m}^{2}$ (17.65 \%). The Malpelo FFS, in the oceanic zone, displayed very low fish larvae abundance compared to the other areas, with the species Vinciguerria lucetia predominating, with 93 larvae/10 m² (48.69 \%). In November 2009, Engraulidae eggs were found in the Gorgona NNP, a finding that might be normal. However, it did not have a high abundance. Similarly, it is surprising that eggs of this family were found in the surroundings of Malpelo, at night to the west and by day to the south. 


\section{DISCUSIÓN}

Considerando las condiciones de temperatura superficial registradas durante noviembre/09 para las tres áreas muestreadas se puede determinar que la media para el PNN Gorgona y el PNN Sanquianga se encuentra en el rango de temperaturas medias. Estos valores son característicos de aguas cálidas. Mientras que los valores de salinidad son variables, la media encontrada para el área del PNN Sanquianga se encuentra en el rango de salinidades bajas, lo que es normal pues su posición en la zona nerítica y que hace que se encuentre influenciada por el gran aporte de los ríos Patía y Sanquianga.

Por su parte las áreas del PNN Gorgona y el SFF Malpelo presentaron salinidades en el rango de medias a altas, lo que también es normal para sus zonas y el mes de muestreo, dado que las dos áreas protegidas se encuentran más alejadas de costa y por lo tanto con menor aporte fluvial. Esto corresponde a las condiciones normales para el área y época que va de mayo a diciembre con bajos valores de salinidad superficial y una termoclina profunda (40 a $50 \mathrm{~m}$ ) (Stevenson et al. 1970; Giraldo, 2008; Giraldo et al., 2008a). Mientras la temperatura para el SFF Malpelo se encontró en el rango de altas, lo que coincide con lo registrado para 2009 acerca de la presencia de un posible evento El Niño (BAC, 2009). Estos eventos generan importantes impactos climáticos, oceanográficos, biológicos y económicos en todo el planeta (Chávez, 1987; Mann y Lazier, 1996; Levinton, 2001; Franco-Gordo et al., 2004), produciendo un descenso en la tasa de producción primaria y una disminución en la composición y biomasa zooplanctónica, que afecta la sobrevivencia, reproducción y distribución de los organismos de niveles tróficos superiores como peces, aves y mamíferos (Chávez, 1996; Martínez-Aguilar et al., 2010).

Los valores de biomasa fueron relativamente estables en el rango de medias durante noviembre de 2009 para las tres áreas muestreadas, lo que evidenció un aporte de producción secundaria importante que aparentemente no se vio afectada por los valores altos de temperatura que se presentaron en el mes muestreado. Noviembre de 2009 no fue un mes importante para el desove y alevinaje de muchas especies de peces, pues entre $60 \%$ y $95 \%$ de las estaciones presentaron abundancias bajas de huevos y larvas para Sanquianga, Gorgona y Malpelo; esto también puede deberse a que el evento El Niño también incide en el reclutamiento de larvas y la tasa de mortalidad natural

\section{DISCUSSION}

Sea surface temperature at Gorgona and Sanquianga in November 2009 fell within the average ranges. These values are characteristic of warm waters. Average salinity at Sanquianga was low, which is to be expected given its position in the neritic zone and because it is influenced by large quantities of fresh water from the Patía and Sanquianga rivers.

For their part, salinity in the areas sampled in the Gorgona NNP and the Malpelo FFS were in the medium to high ranges, a result that is also to be expected in these areas and at the time of year, as both protected areas are far away from the coast and less prone to fluvial influence. This corresponds to the normal conditions found in these areas and season (May to December), characterized by low surface salinity values and a marked thermocline (at 40 to $50 \mathrm{~m}$ ) (Stevenson et al. 1970; Giraldo, 2008; Giraldo et al., 2008a). For its part, the temperature in the Malpelo FFS was in the high range, coinciding with temperatures recorded for 2009 that were associated with a possible El Niño event (BAC, 2009). Events of this kind have significant climatic, oceanographic, biological and economic consequences for the entire planet (Chávez, 1987; Mann and Lazier, 1996; Levinton, 2001; Franco-Gordo et al., 2004), negatively affecting primary production and reducing the composition of the zooplanktonic biomass, which in turn affects the survival, reproduction and distribution of organisms at higher trophic levels, such as fish, birds and mammals (Chávez, 1996; Martínez-Aguilar et al., 2010).

In November 2009, biomass values were relatively stable, within average ranges for the month in the three areas sampled, providing evidence of significant secondary production that was apparently not affected by the high temperatures recorded for that month. November 2009 was not a significant spawning month and yolk-sac larvae were scarce, given that between $60 \%$ and $95 \%$ of the stations had low levels of abundance of eggs and larvae in Sanquianga, Gorgona and Malpelo. This might also be partially explained by the fact that the El Niño event is likely to have affected both the recruitment of larvae and the natural mortality rate of ichthyoplankton (Connol and Roughgarden, 1999; Hopcroft et al., 2002; Lavaniegos et al., 2002). During November 2009, the Sanquianga NNP had the greatest relative abundance, followed by the Gorgona NNP and the Malpelo FFS, while the Gorgona NNP was richest in species, followed by the Sanquianga NNP and the Malpelo FFS. 
del ictioplancton (Connoly y Roughgarden, 1999; Hopcroft et al., 2002; Lavaniegos et al., 2002). Durante noviembre de 2009, el PNN Sanquianga presentó la mayor abundancia relativa, seguido por el PNN Gorgona y SFF Malpelo. Mientras la mayor riqueza de especies se encontró en el PNN Gorgona, seguido del PNN Sanquianga y el SFF Malpelo.

El área protegida del PNN Sanquianga, ubicada en la zona costera presentó la mayor abundancia, dominada por Cetengraulis mysticetus, la cual se constituye en una de las principales especies desde el punto de vista ecológico y económico para la zona costera, ya que soporta la base de la cadena trófica y en su momento era la materia prima de la industria de harina y aceite de pescado (Beltrán-León, 1992; Beltrán-León et al., 1994; Zapata et al., 2013). El PNN Gorgona presentó la mayor diversidad y riqueza de las tres áreas, lo que puede ser normal como zona intermedia, dado que en ella pueden confluir especies tanto de la zona costera como de la oceánica, pero con abundancia más baja, dominada por Bregmaceros bathymaster de importancia ecológica. El SFF Malpelo ubicado en la zona oceánica presentó menos abundancia de larvas que Gorgona y Sanquianga, lo que es normal para sistemas oligotróficos oceánicos tropicales que presentan menores abundancias, dominada por la especie Vinciguerria lucetia de importancia ecológica.

La disminución drástica en la abundancia de huevos y larvas de peces para noviembre en Malpelo estuvo probablemente acentuada como una respuesta de los organismos a las altas temperaturas que se presentaron durante noviembre de 2009 en esta zona $\left(>28,5^{\circ} \mathrm{C}\right)$, coincidiendo con lo registrado por el Boletín de Alerta Climática (BAC, 2009) de julio de 2009 que reporta el desarrollo de un evento El Niño, que se extendió hasta el primer trimestre de 2010. En dicho boletín, el Centro de Control Contaminación del Pacífico (CCCP) manifiesta que durante el monitoreo de julio de 2009, se presentó una anomalía positiva a nivel superficial de $0,72{ }^{\circ} \mathrm{C}$ respecto a la media histórica.

El empobrecimiento de los hábitats pelágicos durante la fase cálida ENOS es uno de los efectos más descritos en la literatura (Martínez-Aguilar et al., 2010). Para 2009, se encontraron huevos de la familia Engraulidae en abundancia muy alta en Gorgona y muy baja en los alrededores de Malpelo, en el occidente de noche y en el sur de día; cabe resaltar que es la primera vez que esta familia compuesta por pequeños pelágicos costeros, es recolectada en Malpelo, que por su característica oceánica no es el lugar
The protected area of Sanquianga NNP, located in the coastal zone, had the highest levels of abundance, Cetengraulis mysticetus being the most abundant species, and one of the zone's most important from an ecological and economic point of view, as it is at the bottom of the food web and, in the past, was also the main raw material for the fish meal and fish oil industries (Beltrán-León, 1992; Beltrán-León et al., 1994; Zapata et al., 2013). Of the three areas, the Gorgona NNP displayed the greatest levels of diversity and richness, a finding that might be expected for an intermediate zone, as species from the coastal and the oceanic zones may be present there, though at lower levels of abundance. The predominant species was the ecologically important Bregmaceros bathymaster. The Malpelo FFS, located in the oceanic zone, was less abundant in larvae than Gorgona and Sanquianga, which is normal for tropical oceanic oligotrophic systems, that display lower levels of abundance. The dominant species was the ecologically important Vinciguerria lucetia.

It is probable that the drastic reduction in the abundance of eggs and fish larvae in Malpelo in November reflected the response of organisms to the high temperatures that characterized the zone in $2009\left(>28.5^{\circ} \mathrm{C}\right)$, as recorded in the July 2009 Boletín de Alerta Climática [Climate Alert Bulletin] (BAC, 2009), which reported on an El Niño event that lasted into the first quarter of 2010. In the bulletin, the Centro de Control de Contaminación del Pacífico (Pacific Pollution Control Center, CCCP) reported a positive anomaly of $0.72{ }^{\circ} \mathrm{C}$ compared to the historical average for the monitoring it carried out in July 2009.

The impoverishment of pelagic habitats during the warm phase of the El Nino Southern Oscillation (ENSO) is one of the effects that has been most frequently described in the literature (Martínez-Aguilar et al., 2010). In 2009, eggs of the Engraulidae family were found in great abundance in Gorgona but were decidedly scarce around Malpelo (to the west at night and to the south during the day). It is worth stressing that this was the first time that individuals of this family were collected in Malpelo, which - because of its oceanic location - is not the typical place to find a family that is considered coastal pelagic typically found between 8 and $12 \mathrm{~km}$ offshore, at depths not exceeding $25 \mathrm{~m}$ (Chirichigno, 1998). This is likely explained by possible changes in the system of currents in the Colombian Pacific, which enabled members of this family to disperse to zones beyond their habitual distribution areas. This is consistent with the suggestion by López-Peralta (1984), who argued 
típico de una especie considerada pelágica costera de aguas tropicales y subtropicales distribuida entre los 8 y $12 \mathrm{~km}$ mar afuera, y a profundidades hasta de $25 \mathrm{~m}$ (Chirichigno, 1998). Lo anterior probablemente como un resultado de posibles alteraciones en el sistema de corrientes en el Pacífico colombiano, donde esta familia pudo desplazarse a zonas no habituales en su distribución. Esto es consistente con lo indicado por López-Peralta (1984), quien plantea que debido a que los huevos de peces son derivadores pasivos, es de esperar alta frecuencia de los mismos en la parte oceánica influenciados por el patrón de circulación superficial, el cual se ve afectado por la corriente de Colombia, que en noviembre es más intensa (vientos alisios del sur hacia el noroccidente), durante la época de lluvias (mayo-noviembre) el jet de Panamá se debilita, y la circulación en el Pacífico colombiano está dominada por la formación de un giro anticiclónico en la zona central (Rodríguez-Rubio et al., 2003; Devis-Morales et al., 2008). En términos generales se ha identificado a la oscilación estacional de los vientos alisios como el principal forzante atmosférico, que modula el patrón de circulación de mesoescala y productividad regional (Rodríguez-Rubio y Giraldo, 2011). Esto implica necesariamente el transporte de huevos fuera de la costa, aumentando su densidad en la parte oceánica. De igual manera se nota una posible respuesta de la familia Engraulidae a los cambios medioambientales anómalos (altas temperaturas) que se presentaron (BeltránLeón, 2002).

El análisis de comunidad NMS fue muy consistente ya que permite observar la agrupación de las estaciones y las especies por área, lo que respalda la ubicación espacial de las áreas así: en la zona costera el PNN Sanquianga con la mayor abundancia representada por Cetengraulis mysticetus, en la zona intermedia el PNN Gorgona representada por Bregmaceros bathymaster y en la zona oceánica el SFF Malpelo representada por Vinciguerrria lucetia, evidenciando diferencias en los parámetros ambientales que inciden en la distribución de las larvas, mostrando también familias exclusivas para cada área.

\section{CONCLUSIONES}

Noviembre de 2009 no fue un mes importante para el desove y alevinaje de muchas especies de peces, ya que se presentaron abundancias bajas en las áreas protegidas. El PNN Sanquianga, ubicado en la zona costera, presentó las mayores abundancias de larvas de la familia Engraulidae (carduma), mientras el PNN Gorgona presentó las mayores abundancias de larvas de peces y el SFF Malpelo presentó that, as fish eggs float passively, they should be expected to occur in numbers in a part of the ocean influenced by the pattern of surface circulation, itself affected by the Colombian current, which is strongest in November (trade winds blowing from the south to the northwest), and by the weakening of the Panama Jet during the rainy season (May-November), while the Colombian Pacific circulation is dominated by the formation of an anticyclonic rotation (Rodríguez-Rubio et al., 2003; Devis-Morales et al., 2008). In general terms, seasonal oscillations in the trade winds have been found to constitute the principal atmospheric driver modulating the pattern of mesoscale circulation and regional productivity (Rodríguez-Rubio and Giraldo, 2011). This necessarily implies the transport of eggs away from the coast, increasing their density in the oceanic zone. Similarly, it is possible that the Engraulidae family was responding to the anomalous environmental changes (high temperatures) it faced (Beltrán-León, 2002).

The NMS analysis of the community was very consistent, in that it made it possible to visualize the grouping of the stations and species by area, justifying the choice of locations, as follows: the coastal zone of the Sanquianga NNP where Cetengraulis mysticetus dominated, the Gorgona NNP represented by Bregmaceros bathymaster and the oceanic zone of the Malpelo FFS where Vinciguerrria lucetia was the most abundant. These findings illustrate that differences in the environmental parameters influence the distribution of the larvae as well as the families that were exclusive to each zone.

\section{CONCLUSIONS}

For many fish species, November 2009 was not a significant spawning month and yolk-sac larvae were not abundant in the protected areas. The greatest abundance of larvae in the Sanquianga NNP, in the coastal zone, came from Engraulidae, while the Gorgona NNP presented the greatest abundance of fish larvae and the Malpelo FFS the lowest abundance of eggs and fish larvae, probably the result of the response of organisms to the high temperatures experienced during November 2009.

The principal families captured were, by area, Engraulidae with Cetengraulis mysticetus (Sanquianga NNP), Bregmacerotidae represented by Bregmaceros bathymaster (Gorgona NNP) and Phosichthyidae in the form of Vinciguerria lucetia (Malpelo FFS). The NMS analysis of the community was very consistent, confirming 
las menores abundancias de huevos y larvas de peces, probablemente como una respuesta de los organismos a las altas temperaturas que se presentaron durante noviembre de 2009.

Las principales familias capturadas y representativas de cada área fueron Engraulidae con Cetengraulis mysticetus (PNN Sanquianga), Bregmacerotidae con Bregmaceros bathymaster (PNN Gorgona) y Phosichthyidae con Vinciguerria lucetia (SFF Malpelo). El análisis de comunidad NMS fue muy consistente evidenciando la separación de las áreas en costera para el PNN Sanquianga, intermedia con el PNN Gorgona y oceánica con el SFF Malpelo, mostrando diferencias en los parámetros ambientales que inciden en la distribución y exclusividad en las familias de larvas. Los promedios de temperatura encontrados en el SFF Malpelo sugieren la presencia de una anomalía térmica positiva, evidenciando su influencia sobre el patrón de distribución y disminución de la abundancia de ictioplancton, donde también se encontraron huevos de Engraulidae de distribución pelágica costera, probablemente como un resultado de posibles alteraciones en el sistema de corrientes en el Pacífico colombiano, donde esta familia pudo desplazarse a zonas no habituales en su distribución.

\section{AGRADECIMIENTOS}

A los funcionarios de las áreas protegidas Sanquianga, Gorgona y Malpelo por el apoyo brindado durante las salidas de campo. A los administradores de las áreas por el apoyo logístico durante las expediciones científicas. A Parques Nacionales, Fundación Malpelo, WWF Colombia y Conservación Internacional por el apoyo brindado a través de los diferentes proyectos de cooperación. A las otras entidades participantes de los proyectos y sus respectivos investigadores, por el apoyo brindado. A Julio Herrera y Francisco Álvarez por el apoyo en el análisis estadístico. A Luis Zapata (WWF-Colombia) por la revisión del manuscrito. A Leydi Cuadros (WWF-Colombia) por la elaboración de los mapas. the separation of the areas into coastal, intermediate and oceanic zones (respectively, the Sanquianga and Gorgona NNPs and the Malpelo FFS), demonstrating in this way the differences in the environmental parameters that influenced the distribution and exclusivity of larvae across the different families. The average temperatures found in the Malpelo FFS suggest the presence of a positive thermal anomaly, showing that this exerted influence on the distribution pattern and reduced abundance of ichthyoplankton. In this zone, eggs of pelagic coastal Engraulidae were also found, probably as a result of changes to the system of currents in the Colombian Pacific, which allowed members of the family to disperse to zones in which they are not usually found.

\section{ACKNOWLEDGMENTS}

We wish to thank the officials working in the protected areas of Sanquianga, Gorgona and Malpelo for the support they offered during field trips, as well as the administrators of the areas for the logistical support provided. We also thank the Sistema de Parques Nacionales Naturales (System of Natural National Parks), the Fundación Malpelo, WWF-Colombia and Conservation International for the financial support they provided in the form of project grants. Our gratitude, furthermore, to the other organizations involved in the projects and the researchers working with them. Finally, our thanks to Julio Herrera and Francisco Álvarez for their help with the statistical analyses, to Luis Zapata (WWF-Colombia) for reviewing the text and to Leydi Cuadros (also WWF-Colombia) for preparing the maps. 


\section{BIBLIOGRAFIA / LITERATURE CITED}

Beltrán-León, B.S. 1992. Identificación y descripción de los tipos de huevos, larvas y post-larvas de Engraulidos y Clupeidos (Pisces, Clupeiformes) en el Pacífico colombiano febrero-marzo de 1991. Tesis Biol. Énfasis Mar. Univ. Valle, Cali. 134 p.

Beltrán-León, B. S. 2002. Changes in the distribution, abundance, and spawning season of the anchovy Cetengraulis mysticetus, in the Pacific Ocean off Colombia during the Events of El Niño and La Niña. Invest. Mar., 30(1): 106-107.

Beltrán-León, B. S. 2007. Caracterización del ictioplancton en el transecto Buenaventura-Malpelo. En: DIMAR-CCCP y Uaespnn-DTSO (Eds). Santuario de Fauna y Flora Malpelo: descubrimiento en marcha. Serie Publ. Esp. DIMAR, 5: 73-96.

Beltrán-León, B. S. y R. Ríos. 2000. Estadios tempranos de peces del Pacífico colombiano. Instituto Nacional de Pesca y Acuicultura INPA, Buenaventura. $727 \mathrm{p}$.

Beltrán-León, B. S., G. E. Ramos, J. C. Escobar y J. A. Tovar, 1994. Distribución y abundancia de huevos y larvas de Opisthonema spp. (Gill 1961) y Cetengraulis mysticetus (Günther 1866) (Pisces: Clupeiformes) en el Pacífico colombiano, durante enero de 1993. Bol. Cient. INPA, 2: 181-199.

BAC.2009. Comisión Permanente del Pacífico Sur (CPPS), Boletín de alerta climático. http://www.inocar.mil.ec/boletin/BAC/bac226.pdf.

Chávez, F.P. 1987. El Niño y la Oscilación del Sur. Invest. Cienc., 128: 46-55.

Chávez, F.P. 1996. Forcing and biological impact of onset of the 1992 El Niño in central California. Geophys. Res. Lett., 23: 265-268.

Chirichigno, N. 1998. Clave para identificar los peces marinos del Perú. 2a ed. IMARPE Pub. Especial. El Callao. 496 p.

Connoly, S.R. and J. Roughgarden. 1999. Increased recruitment of northeast Pacific barnacles during the 1997 El Niño. Limnol. Oceanogr., $44: 466-469$.

Devis-Morales, A., W. Schneider, R.A. Montoya-Sánchez and E. Rodríguez-Rubio. 2008. Monsoon-like winds reverse oceanic circulation in the Panama Bight. Geophys. Res. Lett., 35: L20607. DOI: 10.1029/2008GL035172.

Escarria, E., B. Beltrán-León and A. Giraldo. 2007. Ichthyoplankton in the Nacional Natural Park Isla Gorgona (Pacific Ocean of Colombia) during September 2005. Invest. Mar., 35(2): 127-133.

Franco-Gordo, C., E. Godínez-Domínguez, A.E. Filonov, I.E. Tereshchenko and J. Freire. 2004. Plankton biomass and larval fish abundance prior to and during El Niño period of 1997-1998 along the central Pacific coast of México. Progr. Oceanogr., 63: 99-123.

Giraldo, A. 2008. Variabilidad espacial de temperatura, salinidad y transparencia en el ambiente pelágico del PNN Gorgona durante septiembre 2007 y marzo 2008. Bol. Cient. CIOH, , 26: 157-163.

Giraldo, A., E. Rodríguez-Rubio y F. Zapata. 2008. Condiciones oceanográficas en isla Gorgona, Pacífico oriental tropical de Colombia. Lat. Am. J. Aquat. Res., 36(1), 121-128.

Giraldo, A., B. Valencia, J.D. Acevedo y M. Rivera. 2014. Fitoplancton y zooplancton en el área marina protegida de isla Gorgona, Colombia, y su relación con variables oceanográficas en estaciones lluviosa y seca. Rev. Biol. Trop vol. 62 suppl.1

Hesterberg, T. C. 2015. What teachers should know about the bootstrap: resampling in the undergraduate statistics curriculum. Am. Stat., 69 (4): $371-386$. https://doi.org/10.1080/00031305.2015.1089789.

Hopcroft, R.R., C. Clarke and F.P. Chávez. 2002. Copepod communities in Monterey Bay during the 1997-1999 El Niño and La Niña. Progr. Oceanogr., 54: 251-264.

Lavaniegos, B.E., L.C. Jiménez-Pérez and G. Gaxiola-Castro. 2002. Plankton response to El Niño 1997-1998 and La Niña 1999 in the southern region of the California Current. Progr. Oceanogr., 54: 33-58.

Levinton, J.S. 2001. Marine biology: function, biodiversity ecology. Oxford University Press, New York. 515 p.

López-Peralta, R.H. 1984. Descripción y abundancia del ictioplancton entre 0 y 10 m de profundidad para el Pacífico colombiano (nov. 1982). Tesis Biología Marina. Univ. Jorge Tadeo Lozano., Bogotá. 218 p.

Mann, K.H. and J.R. Lazier. 1996. Dynamics of marine ecosystems: biological-physical interactions in the oceans. Blackwell Science, Boston. 394 p.

Martínez-Aguilar, T. I., A. Giraldo y E. Rodríguez-Rubio. 2010. Ictioplancton en la zona costera del Pacífico colombiano durante la fase terminal de El Nino 2006 2007. Lat. Am. J. Aq. Res., 38(1):151-166 DOI: 10.3856/vol38-issue1-fulltext-14

Moser, G. (Ed.) 1996 The early stages of fishes in the California Current Region. CalCOFI, Atlas No. 33. 1505 p.

Rodríguez-Rubio, E. y A. Giraldo. 2011. Características oceanográficas en la isla Malpelo y su relación con la cuenca oceánica del Pacífico colombiano. Bol. Invest. Mar. Cost. 40 (Supl. Esp.): 19-32.

Rodríguez-Rubio, E., W. Schneider and R. Abarca del Río. 2003. On the seasonal circulation within Panama Bight derived from satellite observations of winds, altimetry and sea surface temperature. Geophys. Res. Lett., 30: 1410-1413.

Rueda-Montenegro, C. y B. Beltrán-León. 1992. Ictioplancton de las familias Clupeidae y Engraulidae en el litoral pacífico colombiano. Mem. VIII Sem. Nal. Cienc. Tecnol. Mar Congr. Centroam. Car. Cienc. Mar, Santa Marta. 785-743 p. 
Smith, L. y S. Richardson. 1979. Técnicas estándar para prospecciones de huevos y larvas de peces pelágicos. FAO. Doc. Tec. Pesca, 175, 107 p.

Stevenson, N., O. Guillén and J. Santoro. 1970. Marine atlas of the Pacific coastal waters of South America. Univ. Calif. Press. 23 p.

Swearer, S. E., J. E., Caselle, D. W. Lea and R. R. Warner. 1999. Larval retention and recruitment in an island population of coral-reef fish. Nature, 402: 799-802.

Welch, B.L. 1951. On the comparison of several mean values: An alternative approach. Biometrika, 38: 330-336.

Zapata, L., J. Herrera, B. Beltrán-León, P. Jiménez, L. Prieto, C. Guevara-Flecher y E. Zambrano. 2011. Estado actual de la pesquería de pequeños pelágicos en el Pacífico colombiano; 157-173. En: Díaz, J.M., C. Vieira y G. Melo (eds.), Diagnóstico de las principales pesquerías del Pacífico colombiano. Fundación Marviva - Colombia, Bogotá.

Zapata, L. A., B. S, Beltrán-León, J. C. Herrera, P. Jiménez-Tello, L. M. Prieto, R. A. Baos, C. E. Guevara and E. Zambrano. 2013. Evaluation of the current state of small pelagic fisheries in the Colombian Pacific: ensuring the sustainability of the resource and evaluating its response to climate events. Adv. Goesci., 33: 63-68.

RECIBIDO/RECEIVED: 25/07/2020

ACEPTADO/ACCEPTED: 05/05/2021 